\title{
Targeting the Epidermal Growth Factor Receptor in EGFR-Mutated Lung Cancer: Current and Emerging Therapies
}

\author{
Karam Khaddour ${ }^{1, *}$, Sushma Jonna ${ }^{1}$, Alexander Deneka ${ }^{2}{ }^{3}$, Jyoti D. Patel ${ }^{3}$, Mohamed E. Abazeed ${ }^{4}$, \\ Erica Golemis $\left.{ }^{2} \mathbb{(}\right)$, Hossein Borghaei ${ }^{5}$ and Yanis Boumber ${ }^{3,6, *}$ \\ 1 Division of Hematology and Oncology, University of Illinois at Chicago, Chicago, IL 60612, USA; \\ sjonna@uic.edu \\ 2 Fox Chase Cancer Center, Program in Molecular Therapeutics, Philadelphia, PA 19111, USA; \\ alexander.deneka@fccc.edu (A.D.); erica.golemis@fccc.edu (E.G.) \\ 3 Robert H. Lurie Comprehensive Cancer Center, Division of Hematology/Oncology, \\ Feinberg School of Medicine, Northwestern University, Chicago, IL 60611, USA; \\ jd-patel@northwestern.edu \\ 4 Robert H. Lurie Comprehensive Cancer Center, Department of Radiation Oncology, \\ Feinberg School of Medicine, Northwestern University, Chicago, IL 60611, USA; \\ mabazeed@northwestern.edu \\ 5 Fox Chase Cancer Center, Department of Hematology and Oncology, Philadelphia, PA 19111, USA; \\ hossein.borghaei@fccc.edu \\ 6 Institute of Fundamental Medicine and Biology, Kazan Federal University, 420008 Kazan, Russia \\ * Correspondence: kkhadd2@uic.edu (K.K.); yanis.boumber@northwestern.edu (Y.B.)
}

\section{check for} updates

Citation: Khaddour, K.; Jonna, S.; Deneka, A.; Patel, J.D.; Abazeed, M.E.; Golemis, E.; Borghaei, H.; Boumber, Y. Targeting the Epidermal Growth Factor Receptor in EGFR-Mutated Lung Cancer: Current and Emerging Therapies. Cancers 2021, 13, 3164. https://doi.org/10.3390/ cancers13133164

Academic Editor: Subba Rao Digumarthy

Received: 2 May 2021

Accepted: 19 June 2021

Published: 24 June 2021

Publisher's Note: MDPI stays neutral with regard to jurisdictional claims in published maps and institutional affiliations.

Copyright: (C) 2021 by the authors Licensee MDPI, Basel, Switzerland. This article is an open access article distributed under the terms and conditions of the Creative Commons Attribution (CC BY) license (https:/ / creativecommons.org/licenses/by/ $4.0 /)$.
Simple Summary: Epidermal growth factor receptor (EGFR) mutations occur in a significant number of lung cancer patients. Treatment outcomes in this subset of patients has greatly improved over the last decade after the introduction of EGFR tyrosine kinase inhibitors (TKIs), which demonstrated high efficacy and improved survival in randomized clinical trials. Although EGFR TKIs became the standard of care in patients with EGFR-mutated lung cancer, resistance almost inevitably develops. This constitutes a major challenge and creates an unmet need for novel therapies and new approaches to ameliorate or overcome this resistance. In this review we discuss currently approved TKIs for the targeted management of EGFR-mutated lung cancer. We also review common mechanisms of resistance to EGFR-targeted therapies and describe promising approaches that may mitigate resistance.

Abstract: Epidermal growth factor receptor-targeting tyrosine kinase inhibitors (EGFR TKIs) are the standard of care for patients with EGFR-mutated metastatic lung cancer. While EGFR TKIs have initially high response rates, inherent and acquired resistance constitute a major challenge to the longitudinal treatment. Ongoing work is aimed at understanding the molecular basis of these resistance mechanisms, with exciting new studies evaluating novel agents and combination therapies to improve control of tumors with all forms of EGFR mutation. In this review, we first provide a discussion of EGFR-mutated lung cancer and the efficacy of available EGFR TKIs in the clinical setting against both common and rare EGFR mutations. Second, we discuss common resistance mechanisms that lead to therapy failure during treatment with EGFR TKIs. Third, we review novel approaches aimed at improving outcomes and overcoming resistance to EGFR TKIs. Finally, we highlight recent breakthroughs in the use of EGFR TKIs in non-metastatic EGFR-mutated lung cancer.

Keywords: lung cancer; adenocarcinoma; overall survival; EGFR; tyrosine kinase inhibitors; progression-free survival

\section{Introduction}

Targeting activating mutations in the tyrosine kinase epidermal growth factor receptor (EGFR) represents a success story in the treatment of lung cancer, a very commonly diagnosed malignancy that remains the leading cause of cancer-related mortality 
(Figure 1A) [1]. Tyrosine kinase inhibitors for EGFR (EGFR TKIs) were initially developed to target tumors overexpressing EGFR, to counteract the resulting kinase overactivation $[2,3]$. At the time of development of EGFR TKIs, it was unknown that some lung cancers bore activating mutations in EGFR. Despite the fact that initial clinical trials showed higher objective response rates (ORR) with EGFR TKIs compared to chemotherapy in lung cancer (specifically non-small cell lung cancer, NSCLC), these trials did not establish an advantage in the general population for progression-free survival (PFS) or overall survival (OS), as these trials enrolled lung cancer patients irrespective of EGFR mutation status [4-6]. Subsequent studies analyzing molecular alterations in the tumors of lung cancer patients who had an excellent response to EGFR TKIs revealed the presence of unique mutations in EGFR that conferred high sensitivity to EGFR TKIs [7-9]. In a first study, Lynch et al. sequenced the codon region of EGFR in nine lung adenocarcinoma patients who had a major or partial response to gefitinib (a first-generation EGFR TKI), and identified somatic mutations in the EGFR kinase domain [7]. The majority of EGFR mutations were either in-frame deletions of exon 19 or single amino acid substitutions (L858R) in exon 21 and were later termed as sensitizing mutations. Subsequent studies using various EGFR TKIs similarly demonstrated higher ORR and longer PFS compared to platinum-based doublet chemotherapy both in recurrent metastatic lung adenocarcinoma and in frontline treatment of lung adenocarcinoma patients with sensitizing EGFR mutations (in this review we will be using the term lung adenocarcinoma to refer to non-small cell lung cancer with adenocarcinoma histology) [10-26].

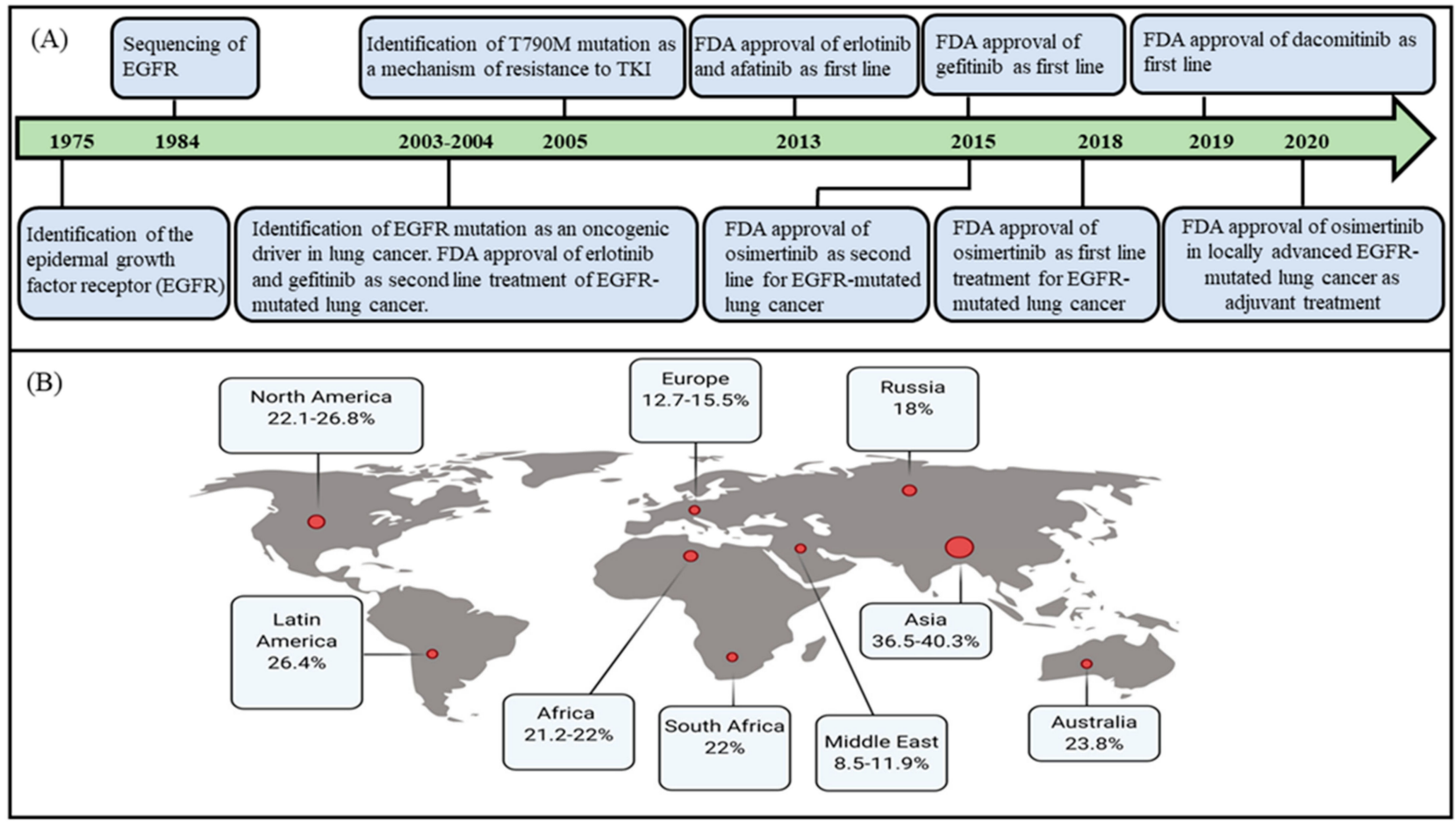

Figure 1. EGFR-mutated lung adenocarcinoma. Panel (A): A timeline of major developments in EGFR-mutated lung adenocarcinoma. Panel (B): The reported frequencies of EGFR mutations in lung adenocarcinoma based on geographic region: frequency in North America [29-31], Asia [27-29], Russia [32], South Africa [33], Middle East and Africa [34], Australia [35], and Latin America [36].

Unexpectedly, the initial trials of EGFR TKIs identified higher ORR and improved outcomes among young women, non-smokers, and Asians with lung cancer [7,8], reflecting the fact that the frequency of EGFR mutations is higher in these patient groups. Ethnicity appears to strongly influence the incidence of detected EGFR mutations, which 
is reflected by the variable distribution of such mutations in regions with demographic profiles reflecting distinct ancestries (Figure 1B).

The highest prevalence of EGFR mutations (30-38\%) occurs in lung adenocarcinoma patients of Southeast Asian ethnicity, including Japan and China [27-29]. In contrast, Caucasians have a lower mutation prevalence of $16-17 \%$ [29-31]. Similarly, ethnicepidemiological studies have identified different frequencies of EGFR mutations in Russia, South Africa, the Middle East and Africa, Australia, and Latin America (18\%, 23\%, 21.2\%, $23.8 \%$, and $26 \%$, respectively) [32-36]. EGFR mutation prevalence can also vary depending on smoking status, sex, and lung cancer histology. For example, the genotyping of 3026 lung adenocarcinoma samples revealed a higher frequency of EGFR mutations in never smokers $(42.5 \%)$ and former smokers $(13.5 \%)$ compared to current smokers $(4.9 \%)$; the most common EGFR mutations in this study included exon 19 deletions and L858R point mutations (Figure 2A,B) [37]. It has been suggested that the higher incidence of EGFR mutations in women compared to men reflects the higher proportion of nonsmokers among females [38]. Moreover, the prevalence of EGFR is highest among patients with NSCLC with an adenocarcinoma histology, while it occurs only rarely in NSCLC patients with squamous cell carcinoma histology and small cell lung cancer (SCLC) [39-41].

(A) Frequency of EGFR Specific Mutations in Lung Adenocarcinoma

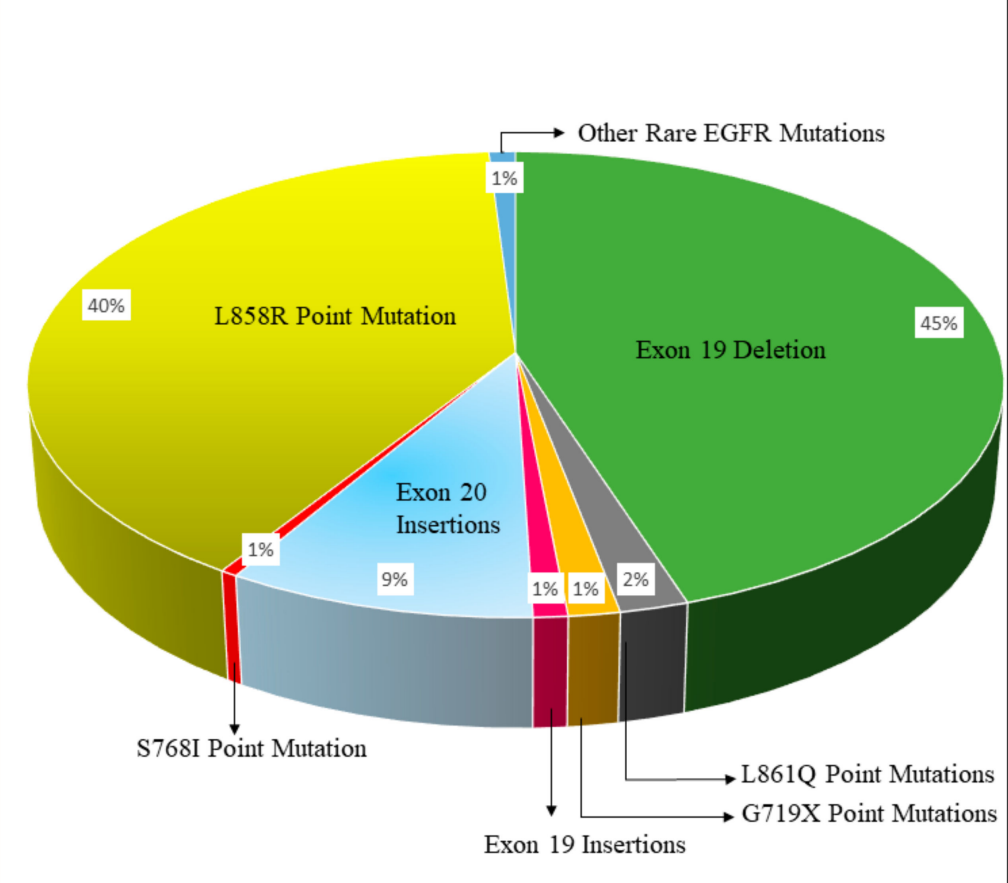

(B) Frequency of EGFR Mutations by Smoking Status

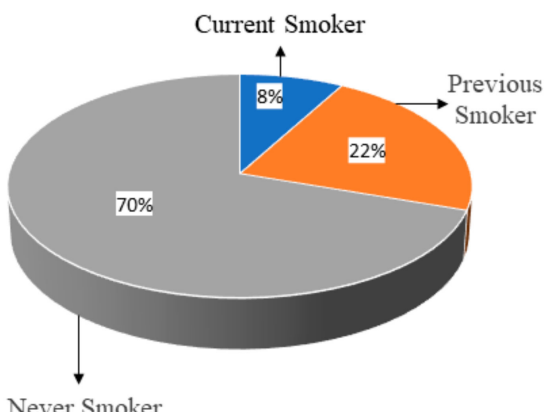

Figure 2. Frequency of EGFR mutations in lung adenocarcinoma. Panel (A): Common and rare EGFR mutations and their frequencies in lung adenocarcinoma [37]. Panel (B): EGFR mutation frequency based on smoking status [37].

The initial approval of EGFR TKIs as standard therapies for patients with specific EGFR mutations (mainly exon 19 deletions and L858R point mutations) was based on the results of randomized clinical trials that demonstrated the superiority of this class of treatment agents versus platinum-based doublet chemotherapy in lung adenocarcinoma (Table 1). Two first-generation EGFR TKIs, erlotinib and gefitinib, demonstrated a significantly longer median PFS compared to platinum-based chemotherapy as front-line treatment in patients with metastatic lung cancer harboring sensitizing EGFR mutations [11-19]. 
Table 1. Clinical Trials of EGFR TKIs in EGFR-mutated Lung Adenocarcinoma and Reported Outcomes.

\begin{tabular}{|c|c|c|c|c|c|c|}
\hline Clinical Trial & Study Design & $\begin{array}{c}\text { Patient Characteristic } \\
\text { Highlights }\end{array}$ & ORR & $\begin{array}{c}\text { mPFS } \\
\text { (Months) }\end{array}$ & mOS & References \\
\hline OPTIMAL & $\begin{array}{c}\text { Erlotinib versus } \\
\text { platinum-based } \\
\text { doublet } \\
\text { chemotherapy }\end{array}$ & $\begin{array}{c}\text { Included: } \\
\text { Presence of } \\
\text { Exon 19del, Exon 21 } \\
\text { missense mutation L858R } \\
\text { Excluded: presence of } \\
\text { brain metastases }\end{array}$ & $\begin{array}{c}83 \% \text { vs. } 36 \% \\
p<0.0001\end{array}$ & $\begin{array}{c}13.1 \text { vs. } 4.6 \\
p<0.0001\end{array}$ & $\begin{array}{c}22.8 \text { vs. } 27.2 \\
p=0.2663\end{array}$ & {$[11,12]$} \\
\hline EURTAC & $\begin{array}{c}\text { Erlotinib versus } \\
\text { platinum-based } \\
\text { doublet } \\
\text { chemotherapy }\end{array}$ & $\begin{array}{c}\text { Included: } \\
\text { Asymptomatic stable brain } \\
\text { metastases } \\
\text { Presence of Exon 19del, } \\
\text { Exon 21 L858R missense } \\
\text { mutation }\end{array}$ & $64 \%$ vs. $18 \%$ & $\begin{array}{l}9.7 \text { vs. } 5.2 \\
p<0.0001\end{array}$ & $\begin{array}{c}19.3 \text { vs. } 19.5 \\
p=0.87\end{array}$ & [13] \\
\hline ENSURE & $\begin{array}{c}\text { Erlotinib versus } \\
\text { platinum-based } \\
\text { doublet } \\
\text { chemotherapy }\end{array}$ & $\begin{array}{c}\text { Included: } \\
\text { Presence of Exon 19del, } \\
\text { Exon } 21 \text { missense L858R } \\
\text { mutation } \\
\text { Excluded: } \\
\text { Presence of brain } \\
\text { metastases }\end{array}$ & $\begin{array}{c}62.7 \% \text { vs. } \\
33.6 \%\end{array}$ & $\begin{array}{l}11 \text { vs. } 5.5 \\
p<0.0001\end{array}$ & $\begin{array}{c}26.3 \text { vs. } 25.5 \\
p=0.607\end{array}$ & [14] \\
\hline WJTOG3405 & $\begin{array}{c}\text { Gefitinib versus } \\
\text { platinum-based } \\
\text { doublet } \\
\text { chemotherapy }\end{array}$ & $\begin{array}{c}\text { Included: } \\
\text { Presence of Exon 19del, } \\
\text { Exon } 21 \text { missense L858R } \\
\text { mutation } \\
\text { Excluded: } \\
\text { Presence of symptomatic } \\
\text { brain metastases }\end{array}$ & $\begin{array}{c}62.1 \% \text { versus } \\
32.2 \% \\
p<0.0001\end{array}$ & $\begin{array}{l}9.2 \text { vs. } 6.3 \\
p<0.0001\end{array}$ & $\begin{array}{c}34.9 \text { vs. } 37.3 \\
p=0.2070\end{array}$ & {$[16,17]$} \\
\hline NEJ002 & $\begin{array}{c}\text { Gefitinib versus } \\
\text { platinum-based } \\
\text { doublet } \\
\text { chemotherapy }\end{array}$ & $\begin{array}{c}\text { Included: } \\
\text { Presence of Exon 19del, } \\
\text { Exon } 21 \text { missense L858R } \\
\text { mutation } \\
\text { Excluded: } \\
\text { Symptomatic brain } \\
\text { metastases } \\
\text { Presence of T790M } \\
\text { missense mutation }\end{array}$ & $\begin{array}{c}73.7 \% \text { vs. } \\
30.7 \% \\
p<0.001\end{array}$ & $\begin{array}{c}10.8 \text { vs. } 5.4 \\
p<0.001\end{array}$ & $\begin{array}{c}30.5 \text { vs. } 23.6 \\
p=0.31\end{array}$ & [15] \\
\hline IPASS & $\begin{array}{c}\text { Gefitinib versus } \\
\text { platinum-based } \\
\text { doublet } \\
\text { chemotherapy }\end{array}$ & $\mathrm{N} / \mathrm{A}$ & $\begin{array}{c}43 \% \text { vs. } 32.2 \% \\
p<0.001\end{array}$ & $\mathrm{~N} / \mathrm{A}$ & $\begin{array}{c}18.8 \text { vs. } 17.4 \\
p=0.109\end{array}$ & {$[18,19]$} \\
\hline LUX-Lung 3 & $\begin{array}{c}\text { Afatinib versus } \\
\text { platinum-based } \\
\text { doublet } \\
\text { chemotherapy }\end{array}$ & $\begin{array}{c}\text { Included: } \\
\text { Presence of Exon 19del, } \\
\text { Exon } 21 \text { missense L858R } \\
\text { mutation or other } \\
\text { mutations }\end{array}$ & $\begin{array}{c}56 \% \text { vs. } 23 \% \\
p=0.001\end{array}$ & $\begin{array}{c}11.1 \text { vs. } 6.9 \\
p=0.001\end{array}$ & $\begin{array}{c}16.6 \text { vs. } 14.8 \\
p=0.60\end{array}$ & [20] \\
\hline LUX-Lung 6 & $\begin{array}{c}\text { Afatinib versus } \\
\text { platinum-based } \\
\text { doublet } \\
\text { chemotherapy }\end{array}$ & $\begin{array}{c}\text { Included: } \\
\text { Presence of Exon 19del, } \\
\text { Exon } 21 \text { missense L858R } \\
\text { mutation or other } \\
\text { mutations including } \\
\text { T790M } \\
\text { Excluded: } \\
\text { Active brain metastases }\end{array}$ & $\begin{array}{c}66.9 \% \text { vs. } 23 \% \\
p<0.0001\end{array}$ & $\begin{array}{l}11 \text { vs. } 5.6 p \\
<0.0001\end{array}$ & $\begin{array}{c}22.1 \text { vs. } 22.2 \\
p=0.76\end{array}$ & [21] \\
\hline
\end{tabular}


Table 1. Cont.

\begin{tabular}{|c|c|c|c|c|c|c|}
\hline Clinical Trial & Study Design & $\begin{array}{c}\text { Patient Characteristic } \\
\text { Highlights }\end{array}$ & ORR & $\begin{array}{c}\text { mPFS } \\
\text { (Months) }\end{array}$ & mOS & References \\
\hline LUX-Lung 7 & $\begin{array}{l}\text { Afatinib versus } \\
\text { gefitinib }\end{array}$ & $\begin{array}{c}\text { Included: } \\
\text { Presence of Exon 19del, } \\
\text { Exon } 21 \text { missense L858R } \\
\text { mutation } \\
\text { Excluded: } \\
\text { Active brain metastases } \\
\text { Included: }\end{array}$ & $\begin{array}{c}70 \% \text { vs. } 56 \% \\
p=0.0083\end{array}$ & $\begin{array}{c}11 \text { vs. } 10.9 \\
p=0.017\end{array}$ & $\begin{array}{c}27.9 \text { vs. } 25 \\
p=0.33\end{array}$ & [22] \\
\hline ARCHER 1050 & $\begin{array}{l}\text { Dacomitinib versus } \\
\text { gefitinib }\end{array}$ & $\begin{array}{l}\text { Presence of Exon 19del, } \\
\text { Exon } 21 \text { missense L858R } \\
\text { mutation including T790M } \\
\text { Excluded: } \\
\text { History of brain metastases }\end{array}$ & $\begin{array}{c}75 \% \text { vs. } 72 \% \\
p=0.4234\end{array}$ & $\begin{array}{l}14.7 \text { vs. } 9.2 \\
p<0.0001\end{array}$ & $\begin{array}{c}34.1 \text { vs. } 26.8 \\
p=0.044\end{array}$ & {$[23,24]$} \\
\hline FLAURA & $\begin{array}{l}\text { Osimertinib versus } \\
\text { erlotinib or } \\
\text { gefitinib }\end{array}$ & $\begin{array}{c}\text { Included: } \\
\text { Presence of Exon 19del, } \\
\text { Exon } 21 \text { missense L858R } \\
\text { mutation or other } \\
\text { mutations } \\
\text { Presence of stable brain } \\
\text { metastases }\end{array}$ & $\begin{array}{c}80 \% \text { vs. } 76 \% \\
0=0.24\end{array}$ & $\begin{array}{c}18.9 \text { vs. } 10.2 \\
p<0.001\end{array}$ & $\begin{array}{c}38.6 \text { vs. } 31.8 \\
p=0.046\end{array}$ & {$[25,26]$} \\
\hline
\end{tabular}

Abbreviations: ORR: objective response rate, mPFS: median progression-free survival, mOS: median overall survival, vs: versus, N/A: not applicable.

EGFR is one of four members of the ERBB protein family, which also includes HER2, ERBB3, and ERBB4. The pan-ERBB inhibitor, afatinib, is a second-generation TKI which also demonstrated longer PFS in metastatic EGFR-mutated lung adenocarcinoma compared to standard chemotherapy [20-22]. Another second-generation EGFR TKI, dacomitinib, was assessed in the ARCHER 1050 trial. In this study, treatment with dacomitinib was associated with a longer median PFS than was seen for gefitinib (mPFS 14.7 versus 9.2 months, respectively), albeit higher drug-related adverse events $[23,24]$. Collectively, these trials established EGFR TKIs as front-line treatments in locally advanced and metastatic (stage IV) lung adenocarcinoma with sensitizing EGFR mutations.

Despite the promising activity of EGFR TKIs, intrinsic or acquired resistance mechanisms limited their efficacy. For example, emergence of a tumor bearing an EGFR T790M mutation in a patient who had disease progression after initial response to gefitinib was first identified in 2005 [42]. Subsequent research established T790M mutation as the main ("gatekeeper") mutation conferring resistance to first- and second-generation EGFR TKIs, occurring at an estimated frequency of $50-70 \%$ in tumors progressing while on EGFR TKI therapy [43-45]. However, T790M has also been detected in tumors previously untreated with EGFR TKs, suggesting an additional role in primary resistance to first- and second-generation TKI [43]. The high prevalence of T790M mutation motivated a search for third-generation EGFR TKIs that are active in the context of this resistant mutation. Among these is osimertinib, which has a high affinity for binding to the ATP pocket in the kinase domain of EGFR and, correspondingly, has excellent activity against T790M-mutated lung adenocarcinoma. The phase-2 AURA2 trial assessing the safety and efficacy of osimertinib in TKI-pretreated patients with EGFR-mutated lung adenocarcinoma bearing T790M mutations demonstrated a 70\% ORR [46]. Subsequently, the phase 3 FLAURA study compared osimertinib to either erlotinib or gefitinib in frontline therapy for EGFR-mutated lung adenocarcinoma. In this trial, osimertinib was associated with a longer mPFS compared to first-generation EGFR TKIs (18.9 months vs. 10.2 months, $p<0.001)$ [25]. An updated survival analysis from the FLAURA trial demonstrated prolonged OS in the osimertinib arm compared to patients who received earlier generation TKI (38.6 months vs. 31.8 months, $p=0.046$ respectively) [26]. Moreover, osimertinib demonstrated higher efficacy in 
controlling intracranial metastatic disease and lower CNS progression rate when compared to first-generation EGFR TKI (6\% vs. $15 \%$ intracranial progression rate respectively) [25].

Despite the substantial improvement in the treatment of EGFR-mutated lung adenocarcinoma, there remain key issues for clinical practice that motivate ongoing research. Herein, we discuss the most common sensitizing EGFR mutations and their clinical relevance to treatment choice. We also discuss the evidence as to the efficacy of EGFR TKIs in tumors bearing less common EGFR mutations. Next, we discuss some important resistance mechanisms implicated in TKI failure. We provide a discussion of available combination and novel therapies that are being studied to improve outcomes and target resistant mechanisms in EGFR-mutated lung cancer. Finally, we highlight the recent breakthrough in the use of EGFR TKIs in non-metastatic lung adenocarcinoma.

\section{Current Treatment Landscape of EGFR-Mutated Lung Adenocarcinoma}

The majority of EGFR mutations affect the intracellular tyrosine kinase domain of the receptor, and encompass a heterogeneous group of mutations in exons 18 to 21 (Figure 3). Activating somatic EGFR mutations, which are considered oncogenic in lung cancer, can be divided into common mutations with known sensitizing activity to TKIs, and uncommon mutations. The common mutations constitute more than $85 \%$ of EGFR somatic mutations in lung adenocarcinoma. These include in-frame deletions in exon $19(45 \%)$ and a missense mutation in exon 21 (L858R) (40\%) [47]. Exon 19 deletions and L858R mutations lead to an enhanced tyrosine kinase activity and increased downstream signaling due to constant dimerization of EGFR which is responsible for its oncogenic potential [48]. These common mutations are highly sensitive to first-, second-, and third-generation EGFR TKIs, and are thereby referred to as sensitizing mutations. Less frequent EGFR mutations constitute the remaining $10-15 \%$ of EGFR-mutated lung adenocarcinoma, and comprise a heterogeneous group of rare mutations with the most common being reported in exon 18 (E709X and G719X), exon 19 (exon 19 insertions), exon 20 (exon 20 insertions and S768I), and exon 21 (L861Q). Importantly, different mutations can occur simultaneously and are referred to as compound or complex mutations; these have been reported in up to $15 \%$ of EGFR-mutated lung adenocarcinoma [49].

The most clinically relevant EGFR TKI resistance mutation is the T790M missense mutation, which occurs in exon 20. The clinical importance of T790M mutation stems from its high frequency in EGFR-mutated lung adenocarcinoma at progression during treatment with first- and second-generation EGFR TKI (50-70\%) [43-45]. This mutation increases ATP affinity at the binding pocket of the receptor and prevents first- and second-generation EGFR TKIs from binding to the ATP region [50]. Lung adenocarcinomas bearing T790M mutations are notoriously resistant to first-generation TKI. Although lung adenocarcinoma cells bearing this mutation are sensitive to high concentrations of second-generation EGFR TKIs in vitro, concentrations effective in controlling growth of these tumors in vivo are too toxic to be used in humans [51]. Therefore, the current standard of care in the frontline setting in many countries (including the US, Japan, and the EU) is osimertinib, due to its high efficacy against T790M mutations; however, in some countries, osimertinib is only available for patients with T790M mutations that have arisen after progressing during treatment with first- or second-generation EGFR TKIs. 


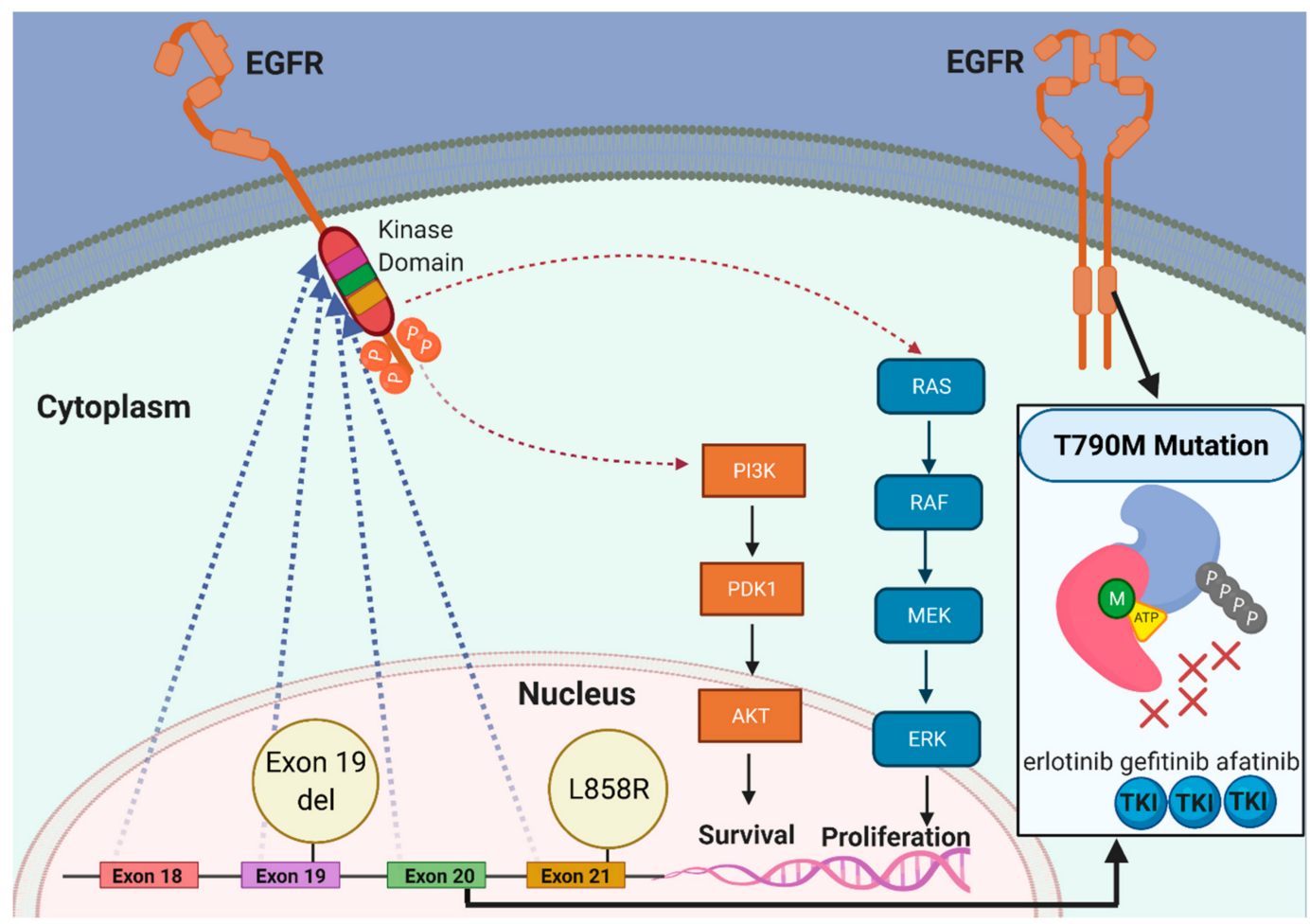

Figure 3. The biology of EGFR mutations in lung cancer. In normal cells, binding of a ligand causes dimerization of EGFR which leads to downstream activation of several pathways such as PI3K/AKT and MAPK/RAF which control cell growth and proliferation. In EGFR-mutated lung cancer, activating somatic mutations in exons 18-21 can lead to constant activation of the EGFR kinase domain with continuous downstream signaling through PI3K/AKT and MAPK/RAF pathways irrespective of ligand binding to growth hormones. This can lead to cell survival, proliferation and resistance to apoptosis. The most common EGFR mutations are exon 19 deletions and a point mutation in exon 21 (L858R). The presence of the point mutation T790M in exon 20 leads to resistance to first- and second-generation EGFR TKIs due to a higher affinity of the ATP-binding pocket in the EGFR to ATP and a lower affinity to first- and second-generation EGFR TKIs such as erlotinib, gefitinib, afatinib, and dacomitinib.

\subsection{EGFR TKIs against EGFR-Mutated Lung Adenocarcinoma with Common Sensitizing EGFR Mutations}

As the majority of patients in the TKI clinical trials in EGFR-mutated lung adenocarcinoma were younger than the general population of lung cancer patients and were selected for good performance status, it has been important to establish safety and efficacy in a real-world setting. After a number of years of use of these drugs, it is clear that EGFR TKIs are effective in controlling EGFR-mutated lung adenocarcinoma, and have a favorable safety and tolerability profile, including in elderly patients. For example, in a multicenter study, Corre et al. demonstrated comparable efficacy and tolerability of first- and second-generation EGFR TKIs in EGFR-mutated lung adenocarcinoma patients $>80$ years old (ORR 63.3\% and mPFS of 11.9 months) [52]. Another large study in Japan demonstrated non-inferior outcomes for safety profile and MPFS in elderly patients with EGFR-mutated lung adenocarcinoma (age $>75$ years old) compared to relatively younger patients who were treated with erlotinib [53].

Real world evidence has been recently reported for osimertinib, with outcomes which replicated clinical trial outcomes [54-56]. As one example, a global real-world study (ASTRIS) of 3015 patients with EGFR T790M lung adenocarcinoma who received osimertinib after progression to EGFR TKIs found an ORR of $75.1 \%$ and mPFS of 11.1 months, with a toxicity profile comparable to the FLAURA study [54]. A retrospective French study of 205 patients (mean age 69.5) who received osimertinib as a second- or third-line therapy after progression on earlier generation EGFR TKIs found PFS and OS similar to those 
observed in clinical trials of osimertinib [55]. Similarly, a Chinese retrospective study of 74 EGFR-mutated lung adenocarcinoma patients who received at least three prior lines of therapy and were later treated with osimertinib found comparable ORR and PFS to randomized clinical trials [56]. Of interest, a recent analysis of 31 patients who were treated with osimertinib suggested a longer mPFS in elderly patients ( $\geq 65$ years) compared to younger patients ( 6.4 months vs. 3.5 months, $p=0.41$ respectively), albeit conclusions of this study are limited by small sample size [57]. Collectively, real-world evidence has yielded similar outcomes to osimertinib clinical trials, causing this agent to be considered the standard of care in the general population including elderly patients with EGFR-mutated lung adenocarcinoma [58].

The superior tolerability of EGFR TKIs compared to chemotherapy in lung cancer patients has been demonstrated consistently in the randomized clinical trials noted in Table 1, and the use of EGFR TKIs was described in some studies to be associated with improved quality of life $[59,60]$. Similarly supporting quality of life, the ability to administer EGFR TKIs orally yields additional benefits to physicians and patients, including reduction of travel during treatment.

The most common adverse events (AEs) reported in the clinical trials of EGFR TKIs are cutaneous and gastrointestinal (GI) toxicities (Figure 4). Mucocutaneous toxicities caused by EGFR TKIs can include acne-like eruption, folliculitis, xerosis, paronychia, mucositis, and stomatitis, which are caused by disrupted function of keratinocyte in the epidermis [61]. Of interest, several reports including a recent meta-analysis suggested a correlation between the development of skin toxicities and higher response rates to early generation EGFR TKIs [62]. GI toxicity is typically caused by the irritation of the GI mucosa. In addition, other AEs occurring at lower frequencies, have been reported to be associated with use of EGFR TKIs: these include appetite loss, hematologic abnormalities, arthralgia, fatigue, and cough (Figure 4). Notably, osimertinib has the advantage of causing less toxicities and is more well-tolerated compared to first- and second-generation EGFR TKIs owing to its high selectivity to bind mutated EGFR versus wild-type EGFR.

\section{Common EGFR-TKI Related Adverse Events}
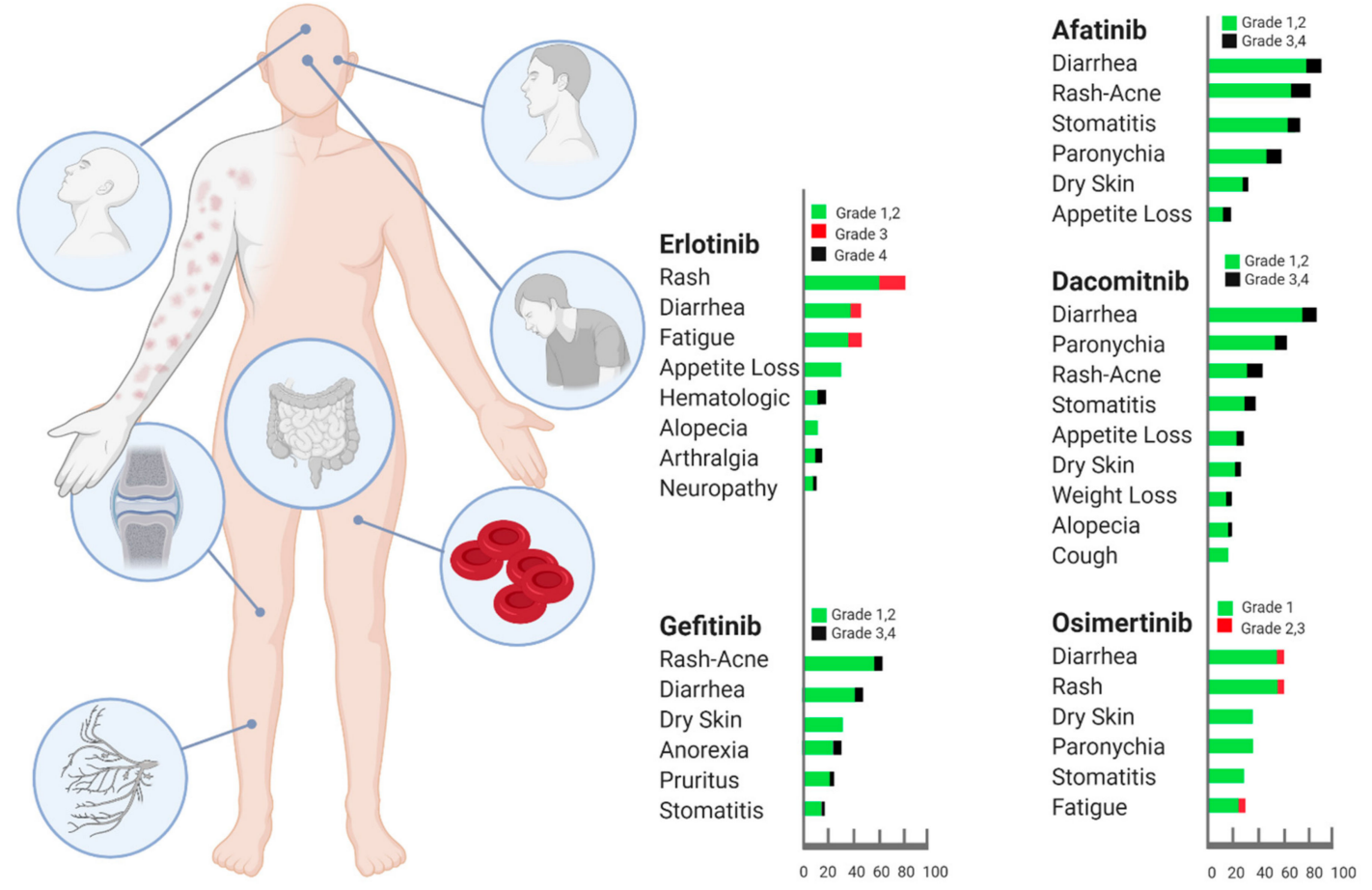

Figure 4. Common reported adverse events from phase 3 randomized clinical trials of EGFR TKIs in EGFR-mutated lung cancer. These include first-generation: erlotinib [13], gefitinib [19], second-generation including afatinib [20], dacomitinib [23], and third-generation osimertinib [25] EGFR TKI drugs. 
The majority of AEs associated with use of EGFR TKIs are mild to moderate. Management of EGFR TKI- associated AEs is based on dose modification, supportive care, and brief medication discontinuation until resolution of toxicity $[63,64]$; the need for permanent discontinuation of EGFR TKIs due to AEs is uncommon.

\subsection{Efficacy of EGFR TKIs in Lung Adenocarcinoma with Rare EGFR Mutations and Exon 19 and 20 Insertions}

Data on the sensitivity of infrequent EGFR mutations (that is, excluding exon 19 deletions and L858R mutations) to currently approved EGFR TKIs varies, and have been reported mostly in retrospective studies and case reports (Table 2). Interestingly, some of the uncommon mutations coexist with exon 19 deletion or L858R mutations; patients with these complex EGFR mutations may have greater sensitivity and achieve longer remission following treatment EGFR TKIs, compared to patients who harbor noncomplex sensitizing mutations [65].

Table 2. Efficacy of select studies with approved EGFR TKIs in lung cancer with uncommon EGFR mutations.

\begin{tabular}{|c|c|c|c|c|c|}
\hline Mutation & $\begin{array}{l}\text { Frequency among } \\
\text { EGFR Mutations }\end{array}$ & First Generation TKI & Second Generation TKI & $\begin{array}{c}\text { Third Generation } \\
\text { TKI }\end{array}$ & References \\
\hline \multicolumn{6}{|c|}{ Exon 18 Mutations } \\
\hline G719X & $1.5-3 \%[66]$ & $\begin{array}{c}\text { (erlotinib or gefitinib) } \\
\text { ORR } 36.8 \% \text { * } \\
\text { mPFS } 6.3 \text { mo [67] }\end{array}$ & $\begin{array}{c}\text { Afatinib ORR } 77.8 \% \\
\text { mPFS } 13.8 \text { mo [68] }\end{array}$ & $\begin{array}{c}\text { Osimertinib ORR } \\
52.6 \% \\
\text { mPFS N/A [69] }\end{array}$ & {$[66-69]$} \\
\hline \multicolumn{6}{|c|}{ Exon 19 Mutations } \\
\hline $\begin{array}{l}\text { Exon } 19 \\
\text { Insertions }\end{array}$ & $1 \%[70]$ & $\begin{array}{c}\text { (erlotinib or gefitinib) } \\
\text { ORR } 40 \% \\
\text { NA [66] }\end{array}$ & $\begin{array}{c}\text { Afatinib } \\
\text { ORR (3 partial responses } \\
\text { in } 4 \text { patients) }[71]\end{array}$ & NA & {$[66,70,71]$} \\
\hline \multicolumn{6}{|c|}{ Exon 20 Mutations } \\
\hline $\begin{array}{l}\text { Exon } 20 \\
\text { Insertions }\end{array}$ & $9 \%[72]$ & $\begin{array}{l}\text { (erlotinib or gefitinib) } \\
\text { ORR } 8-27 \% \\
\text { mPFS } 2-2.5 \text { mo }[73,74]\end{array}$ & $\begin{array}{c}\text { Afatinib } \\
\text { ORR } 8.7 \% \\
\text { mPFS } 2.7 \text { mo [68] } \\
\text { Dacomatinib } \\
* *[75]\end{array}$ & $\begin{array}{l}\text { Osimertinib ORR } \\
\text { 25\% } \\
\text { mPFS } 9.7 \text { mo [76] }\end{array}$ & {$[68,72-76]$} \\
\hline S768I & $0.59 \%[77]$ & $\begin{array}{c}\text { (erlotinib or gefitinib) } \\
\text { ORR } 42 \% \\
\text { NA [66] }\end{array}$ & $\begin{array}{l}\text { Afatinib ORR } 100 \% \\
\text { mPFS } 14.7 \text { mo [68] }\end{array}$ & $\begin{array}{c}\text { Osimertinib ORR } \\
37.5 \% \\
\text { NA [69] }\end{array}$ & {$[66,68,69,77]$} \\
\hline \multicolumn{6}{|c|}{ Exon 21 Mutations } \\
\hline L861Q & $3 \%[78]$ & $\begin{array}{c}\text { (erlotinib or gefitinib) } \\
\text { ORR 39\% } \\
\text { NA [66] }\end{array}$ & $\begin{array}{c}\text { Afatinib } \\
\text { ORR 56.3\% } \\
\text { mPFS } 8.2 \text { mo [68] }\end{array}$ & $\begin{array}{c}\text { Osimertinib ORR } \\
77.8 \% \\
\text { NA [69] }\end{array}$ & {$[66,68,69,78]$} \\
\hline
\end{tabular}

* Higher response rate and longer mPFS were observed with complex G719X mutations coexisting with other EGFR mutations. ** Reported 1 partial response, 2 stable disease, and 2 progressive disease in 6 patients with exon 20 insertions. Abbreviations: NA: not available, ORR: objective response rate, mPFS: median progression-free survival.

The G719X mutation (where X reflects several potential missense substitutions) in exon 18 constitutes approximately 1.5-3\% of all EGFR mutations in lung adenocarcinoma [66]. Chiu et al. demonstrated ORR of $36.8 \%$ and mPFS of 6.3 months in patients with lung tumors bearing a G719X mutation, and treated with erlotinib or gefitinib [67]. The presence of exon 19 deletions or co-occurrence of L858R and G719X mutations was associated with higher response rates and longer PFS compared to G719X mutations alone [66]. Afatinib demonstrated activity against G719X mutations in a pooled analysis from three randomized controlled trials of afatinib (LUX-Lung 2, LUX-Lung 3 and LUX-Lung 6) [68]. Similarly, osimertinib has demonstrated activity against G719X in 19 patients with ORR of 52.6\%; $\mathrm{mPFS}$ had not been reached at the time of publication [69]. 
Insertions in exon 19 are uncommon and account for only 1\% of all EGFR mutations [70]. First-generation EGFR TKI including erlotinib and gefitinib appear to have good efficacy against exon 19 insertions, with an ORR of $40 \%$ (albeit in a very small study of 10 patients) [66]. Afatinib achieved partial responses in a case series of 12 patients with EGFR-mutated lung adenocarcinoma who had exon 19 insertion [71].

In addition to the dominant resistance-associated mutation T790M, there are other low frequency mutations in exon 20. A heterogeneous group of amino acid insertions in exon 20 have been reported, with such insertions constituting 10\% of EGFR-mutated lung adenocarcinoma [72]. The efficacy of first-generation EGFR TKIs against exon 20 insertions is very limited (ORR 8-27\% and mPFS 2-2.5 months), and chemotherapy remains the standard of care in these patients [73,74]. For example, in a French multicenter observational study the ORR in patients with exon 20 insertions who were treated with either erlotinib or gefitinib was $8 \%(n=38)$, with mPFS of 2 months [73]. Another study by Naidoo et al. exploring use of erlotinib in patients with exon 20 insertions reported an ORR of $27 \%$ ( 3 of 11 patients) and mPFS of 2.5 months [74]. Afatinib had limited efficacy in lung cancer patients with exon 20 insertions, based on a pooled analysis by Yang et al., which found an ORR of 8.7\% and mPFS of 2.7 months [68]; similarly, dacomitinib showed modest efficacy in a study of 6 patients ( 1 partial response, 2 stable disease, and 2 progressive disease) [75]. Osimertinib showed also mild activity against exon 20 insertions in a phase II trial that evaluated a dose of $160 \mathrm{mg}$ and found an ORR of $25 \%$ with mPFS of 9.7 months [76]. The relative high frequency of exon 20 insertions compared to other uncommon mutations and the lack of good response to approved TKIs has resulted in an effort to investigate novel therapeutics to overcome this resistant alteration in EGFR-mutated lung adenocarcinoma, discussed below. S768I is another relatively uncommon mutation in exon 20 that accounts for $0.5 \%$ of EGFR-mutated lung cancer [77]. Among EGFR TKIs, afatinib showed the best efficacy with ORR of 100\% and mPFS of 14.7 months, albeit in a very small study of eight patients $[68,69,77]$. Finally, the L861Q mutation, occurring in exon 21 with 3\% frequency, is considered to be sensitive to afatinib and osimertinib (ORR 56.3\% and 77.8\%, respectively) $[66,68,69,78]$.

\subsection{Treatment of Brain Metastases in EGFR-Mutated Lung Adenocarcinoma Using EGFR TKIs}

At least one-third of patients with EGFR-mutated lung adenocarcinoma develop brain metastases during the course of the disease [79]. The incidence of brain metastases is elevated in EGFR-mutated lung adenocarcinoma, with a frequency of associated intracranial disease reaching $31 \%$ in EGFR-mutated lung adenocarcinoma compared to $19.7 \%$ in EGFRwild type lung adenocarcinoma [80,81]. The presence of brain metastases is associated with increased morbidity and shortened OS [82]. Despite the improved outcomes with EGFR TKIs, most clinical trials excluded patients with intracranial disease or had small number of patients with brain metastasis. However, trials of osimertinib were allowed to enroll patients with treated brain metastasis and have confirmed the superiority of osimertinib CNS efficacy over first-generation EGFR TKIs [46]. The FLAURA trial enrolled 128 EGFR-mutated lung adenocarcinoma patients with brain metastases, and reported that median CNS PFS that was not reached at a median follow-up period of 12.4 months with osimertinib, while PFS was 13.9 months with standard first-generation EGFR TKIs (hazard ratio, $0.48 ; p=0.14$ ). CNS objective response rates were $91 \%$ and $68 \%$ in patients with $\geq$ one measurable CNS lesion (odds ratio, $4.6 ; 95 \% \mathrm{CI}, 0.9$ to $34.9 ; p=0.66$ ), and $66 \%$ and $43 \%$ in patients with one measurable and/or non-measurable CNS lesions (odds ratio, $2.5 ; 95 \% \mathrm{CI}, 1.2$ to $5.2 ; p=0.11$ ), for patients treated with osimertinib and first-generation EGFR TKIs, respectively [83]. In addition, based on analysis of predefined subgroups, the progression rate of intracranial disease was found to be lower in patients who were treated with osimertinib versus those who received alternative EGFR TKIs $(6 \%$ versus $15 \%$, respectively) [25]. Similarly, a longer mPFS was maintained in patients with CNS disease who received osimertinib versus those who received chemotherapy (11.7 vs. 5.6 months; $p=0.004$ ) [84]. Interestingly, some evidence suggests an improved outcome in EGFR-mutated lung adenocarcinoma patients with brain metastases who receive initial 
radiation therapy (RT) [85]. Several studies are ongoing to evaluate whether the sequencing of treatment (RT followed by an EGFR TKI) versus deferring RT as a salvage treatment after initial use of an EGFR TKI; could improve outcomes.

\section{Resistance Mechanisms in EGFR-Mutated Lung Adenocarcinoma That Compromise the Use of EGFR TKIs}

Inherent and acquired resistance in EGFR-mutated lung adenocarcinoma pose a major challenge to outcome improvement in lung cancer treatment (Figure 5). The most frequent inherent resistant mechanism to EGFR TKIs is in-frame insertion of base pairs in exon 20 [86]. Acquired resistance can similarly be the result of novel mutations selected in EGFR that alter the ability of TKIs to bind or inhibit the protein. Alternatively, a change in cell phenotype to remove dependence on EGFR signaling, including upregulation of bypass receptor tyrosine kinases (RTKs), and histological transformation into SCLC or epithelial to mesenchymal transition, can cause resistance. Additionally, development of brain metastases has been proposed as a separate category of resistance [87]. Acquisition of a T790M gatekeeper mutation comprises about two thirds of acquired resistance developing during treatment with first- and second-generation EGFR TKIs and this issue has been largely resolved with the development of osimertinib, which has potent activity against T790M mutation. Novel mutations in EGFR that occur during treatment with osimertinib can contribute to disease progression and comprise approximately $6-10 \%$ of resistant mechanisms to osimertinib when it is used in a frontline therapy and $10-26 \%$ if osimertinib is used as a second line treatment [88].

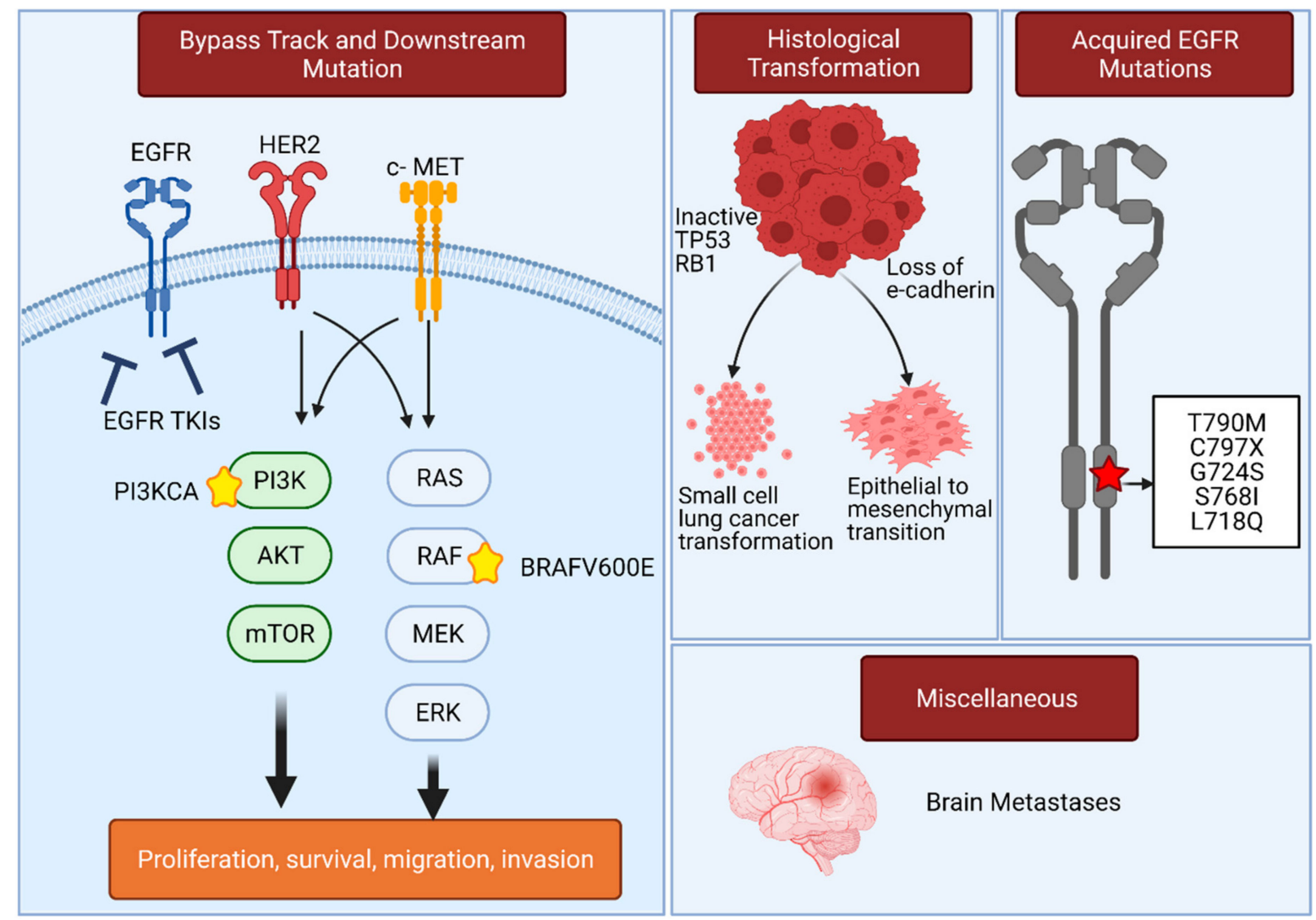

Figure 5. Common resistance mechanisms to EGFR TKIs in EGFR-mutated lung adenocarcinoma. Bypass track signaling include HER2 and c-MET amplification that can lead to parallel activation of downstream signaling, which is able to drive tumor proliferation despite EGFR inhibition. Downstream point mutations increasing activity of the EGFR effector kinases PI3KCA and BRAF ${ }^{\mathrm{V} 600 \mathrm{E}}$ can also lead to a constitutive activation of cancer growth. Histological transformation to SCLC, or epithelial to mesenchymal transition (EMT), contribute to loss of sensitivity to EGFR TKIs in lung adenocarcinoma. Acquired EGFR mutations in the tyrosine kinase domain can lead to increased affinity to ATP versus EGFR TKIs. Other mechanisms are also implicated in resistance to EGFR TKIs such as development of brain metastases. 
Beyond the T790M mutation discussed above, one important mutation that contributes to acquired resistance to EGFR TKIs is the gatekeeper point mutation C797S. Occurring at a frequency of up to $14 \%$, C797S prevents covalent binding of osimertinib to the ATP-binding pocket in EGFR, leading to therapy failure [89].

Establishment of parallel RTK signaling independent of EGFR (a bypass track) is another mechanism that contributes to resistance to TKIs. Among sources of EGFR bypass, MET gene amplification, causing increased activation of the MET kinase, is the most common cause of resistance to early generation EGFR TKIs and osimertinib (at frequencies of $5 \%$ and $15 \%$, respectively) [45,88]. Similarly, amplification of the EGFR paralog ERBB2/HER2 can act as another bypassing oncogenic driver during treatment with EGFR TKIs. The prevalence of HER2 amplifications is higher in EGFR-mutated lung adenocarcinoma treated with early generation EGFR TKIs compared to treatment with osimertinib (5\% versus $1-2 \%$ respectively) $[88,89]$. Other bypass track mutations that have been identified with a lower frequency in case reports include fusions in RET, ALK, and other genes that could act as oncogenic drivers [89]. Emergence of new mutations downstream of EGFR has also been described recently to confer resistance to TKIs and include PI3KCA and $B R A F^{V 600 E}$ mutations [89]. Preclinical studies have also demonstrated intersection between the VEGFR and EGFR pathways in tumor cells, and shown that the activating ligand for vascular endothelial growth factor receptor (VEGFR), VEGF, is sometimes overexpressed in resistant EGFR-mutated lung adenocarcinoma, providing autocrine signaling [90,91].

Phenotypic histological transformation to SCLC represents another major resistance mechanism in EGFR-mutated lung adenocarcinoma [92]. Acquired resistance through histological transformation accounts for up to $15 \%$ of resistant mechanisms to EGFR TKIs [89]. Management of transformed SCLC from EGFR-mutated lung adenocarcinoma is based on use of chemotherapy including etoposide/carboplatin and taxanes, which results in a median OS of 10.9 months [93].

\section{Novel Treatment Approaches in EGFR-Mutated Lung Adenocarcinoma}

Development of novel therapeutics to overcome intrinsic and acquired resistance to EGFR TKIs is an area of extensive effort. Concurrently, ongoing investigations seek to determine whether combination therapies, such as addition of chemotherapy, VEGF/VEGFR2 monoclonal antibodies, and immune checkpoint inhibitors (ICIs) to use with EGFR TKIs could improve treatment outcomes.

\subsection{Combining Chemotherapy and EGFR TKIs}

Preclinical evidence of synergy between chemotherapy and EGFR TKIs in EGFR-mutated lung adenocarcinoma cell models raised the interest in assessing clinical efficacy in patients with EGFR-mutated lung adenocarcinoma [94]. For example, combination treatment with the folate inhibitor pemetrexed delayed the development of resistance to gefitinib in EGFRmutated lung adenocarcinoma cell lines that had sensitizing exon 19 deletion mutations [95]. A phase II randomized trial compared the use of gefitinib versus gefitinib and pemetrexed in patients with EGFR-mutated lung adenocarcinoma. This study demonstrated prolonged mPFS in patients who received combination therapy, but a similar ORR and higher toxicity profile associated with combination treatment [96]. Interestingly, addition of pemetrexed and carboplatin to gefitinib in patients with EGFR-mutated lung adenocarcinoma showed statistically significantly higher ORR and improved OS in two phase III randomized clinical trials over gefitinib alone (75-84\% versus 63-67\%, respectively) and OS (50.9-not reached versus 17-38.8 months, respectively) $[97,98]$. Despite these promising results, the clinical relevance of such studies was impacted by the emergence of osimertinib as first line standard of care. The absence of direct comparison of these combinations with osimertinib and the unblinded design of these trials currently limits clinical applicability of such approaches. An important trial (FLAURA2) is currently underway to investigate the clinical efficacy of the addition of pemetrexed and carboplatin to osimertinib in patients with EGFR-mutated lung adenocarcinoma (NCT04035486, ClinicalTrials.gov). 


\subsection{Combining VEGF/VEGFR2-Directed Monoclonal Antibodies and EGFR TKIs}

VEGF inhibitors inhibited cell growth of EGFR-mutated lung adenocarcinoma in preclinical studies suggesting that simultaneous targeting of both the EGFR and VEGFR signaling pathways could provide clinical advantage [99]. Clinical evidence of an added benefit of combined VEGF and EGFR inhibition is emerging. The phase II clinical trial JO25567 demonstrated a significantly prolonged mPFS in EGFR-mutated lung adenocarcinoma patients who received combination therapy (the VEGF inhibitor bevacizumab and erlotinib) versus those who were treated with single agent EGFR TKI (16 vs. 9.7 months, $p=0.0015$ ) [100]. In contrast, another phase II trial using a similar comparative regimen did not find significant difference of mPFS between in patients treated with the combination [101]. A subsequent phase III randomized clinical trials demonstrated a longer median PFS in patients who received erlotinib and bevacizumab versus patients who received erlotinib monotherapy ( 16.9 vs. $13.3, p=0.016)$; however, final OS analysis did not demonstrate a benefit with the addition of bevacizumab [102,103]. In addition, a recent phase II randomized clinical trial failed to demonstrate improved median PFS in patients with EGFR-mutated lung adenocarcinoma harboring T790M who progressed on prior early generation EGFR TKIs and were randomized to either osimertinib versus osimertinib plus bevacizumab [104].

Taking another approach to targeting VEGF signaling, the RELAY study was a phase III randomized clinical trial that evaluated the addition of the VEGFR2-directed monoclonal antibody, ramucirumab, to erlotinib in EGFR-mutated lung adenocarcinoma patients with defined EGFR TKI sensitizing mutations [105]. This trial showed significantly prolonged median PFS in patients who received erlotinib and ramucirumab versus patients who received erlotinib monotherapy (19.4 vs. 12.4, $p<0.0001)$ [105]. Additional ongoing studies are assessing the efficacy of adding bevacizumab and ramucirumab to osimertinib in frontline therapy (NCT04181060 and NCT03909334, ClinicalTrials.gov).

\subsection{Immunotherapy and Chemo-Immunotherapy in EGFR-Mutated Lung Adenocarcinoma}

Immune checkpoint inhibitors (ICIs) play a transformative central role in the treatment of lung cancer, significantly prolonging OS. The safety and efficacy of ICI in EGFR-mutated lung adenocarcinoma has hence been of considerable interest [106-108]. However, initial studies revealed low response rates to ICIs in patients with EGFR-mutated lung adenocarcinoma who received prior EGFR TKIs [109]. A phase II trial assessed the use of the programmed death-1 (PD-1) targeting antibody pembrolizumab as front-line therapy in EGFR-mutated lung adenocarcinoma patients with programmed death ligand-1 (PD-L1) expression $>50 \%$; there were 0 responses in 10 assessed patients, and one documented death due to pneumonitis within 6 months of treatment initiation [110]. A meta-analysis of several studies concluded that ICIs with either the PD- 1 targeting agents pembrolizumab or nivolumab, or the PD-L1/2-targeting agent atezolizumab were not effective as second line treatment in patients with EGFR-mutated lung adenocarcinoma patients who progressed on prior EGFR TKI treatment [111]. Moreover, the high toxicity observed from various studies that evaluated either combination ICI and EGFR TKIs, or their sequential administration, has decreased the interest in further evaluation of this approach [112].

Of importance, a phase III randomized clinical trial IMpower150 evaluated efficacy of combination of atezolizumab with bevacizumab and chemotherapy in the treatment of lung cancer [113]. This trial included a subset of patients who had EGFR-mutated lung adenocarcinoma and demonstrated longer median PFS in those who received the experimental combination (atezolizumab, bevacizumab, and chemotherapy) compared to patients who received bevacizumab and chemotherapy alone [113]. A follow up exploratory analysisthe IMpower150 trial-analyzed the efficacy of the combination regimen in patients with EGFR-mutated lung adenocarcinoma, most of whom had sensitizing mutations, but who had progressed on earlier treatment with EGFR-targeting TKIs. This trial demonstrated an ORR of $71 \%$ and longer median PFS and median OS (hazard ratio of 0.41 and 0.31 , respectively) [114]. The results of Impower150 have reinvigorated the idea that ICIs could 
have a potential role in the subset of lung cancer patients with EGFR mutations; however, much further study is needed.

\subsection{Novel Treatment Strategies for Lung Cancer with EGFR Exon 20 Insertions}

Exon 20 insertions comprise approximately 3\% of all lung cancer cases and up to $12 \%$ of EGFR-mutated lung adenocarcinoma [115]. As discussed above, currently available EGFR TKIs are thought to have very limited efficacy against exon 20 insertions (median PFS of 2 months) and chemotherapy remains the standard of care in these patients [116]; prognosis for patients treated with chemotherapy is inferior compared to that for patients with lung cancers bearing other sensitizing mutations in EGFR [117]. However, there may be some settings in which EGFR TKIs are effective in these patients. While two studies of osimertinib reported a low ORR of 5\% in 17 lung cancer patients with exon 20 insertion mutations [118,119], one study showed a higher ORR $(25 \%)$; this last study used a higher dose of osimertinib (160 mg versus the typical dose of $80 \mathrm{mg}$ ), and achieved some responses in patients who had progressed on prior therapy [76].

Mobocertinib (TAK-788) is a potent TKI developed to inhibit EGFR and ERBB2/ HER2 [120]. A phase I/II single arm clinical trial evaluated mobocertinib in 27 patients with exon 20 insertions who had progressed on prior treatments; more than a third of these patients had brain metastases [121]. While about a third of patients had grade $\geq 3$ diarrhea, a high ORR of $43 \%$ was observed, and a median PFS of 7.3 months. These results led to FDA breakthrough designation of mobocertinib for the treatment of EGFR-mutated lung adenocarcinoma with exon 20 insertions [121]. Currently, a phase III randomized clinical trial is underway to evaluate the safety and efficacy of mobocertinib versus chemotherapy as a front-line therapy for lung cancer patients with exon 20 insertions (NCT04129502).

Amivantamab is an intravenously delivered bispecific antibody against EGFR and cMET [122,123]. The advantage of this novel monoclonal antibody includes its multimechanistic activity in lung cancer which involves targeting both EGFR and cMET signaling as well as its ability to induce antibody-dependent cytotoxicity in cancer cells. The activity of amivantamab against lung cancer with exon 20 insertion was demonstrated in phase I single arm study of 39 patients [124]. This study demonstrated an ORR of $36 \%$ and median PFS of 8.6 months with only $6 \%$ of grade $>3$ therapy related adverse events (TRAEs), which has resulted in FDA breakthrough designation for patients with exon 20 insertions [124].

Poziotinib is another novel TKI targeting EGFR, HER2/ERBB2, and ERBB4. In the phase II clinical trial ZENITH-20-1, 115 patients with lung cancer with exon 20 insertions who had received at least one prior line of therapy received $16 \mathrm{mg}$ of poziotinib daily to investigate its safety and efficacy [125]. Results of this trial demonstrated an ORR of $19.3 \%$ and a median PFS of 4.2 months; however, more than half of the patients developing grade $\geq 3$ TRAE [125]. These TRAEs required permanent discontinuation of poziotinib in $10 \%$ of the study population, and drug interruption in $88 \%$ of patients; $68 \%$ required dose modification during treatment. Given this high toxicity, subsequent trials are evaluating lower doses of poziotinib.

Finally, CLN-081 is another promising small molecule EGFR TKI that has been developed to target exon 20 insertions in lung cancer. In a phase I/IIa trial evaluating its safety and efficacy, the drug had good tolerability, and two out of five patients had partial response and three had stable disease after treatment initiation [126]. Notably, most of these patients had previously received either poziotinib or mobocertenib [126].

\subsection{Novel TKI and Monoclonal Antibody Treatments Targeting Osimertinib Resistance Mechanisms}

Despite the excellent efficacy of osimertinib in treating metastatic EGFR-mutated lung adenocarcinoma, the inevitable disease progression remains a pressing issue limiting further improvement of patient care. The combined use of gefitinib with osimertinib has been described in a case report of a patient with both T790M and C797S mutations [127]. In this case, there was rapid clearance of the $\mathrm{C} 797 \mathrm{~S}$ subclone despite continued progression of the disease, which suggests that tumors with C797S mutations could be sensitive to 
early generation EGFR TKIs. Similarly, another report demonstrated a response to erlotinib in a patient with EGFR-mutated lung adenocarcinoma who was initially treated with osimertinib and later progressed due to an acquired C797S mutation [128]. These results suggest the need for further investigation to evaluate the efficacy of combining or sequencing early generation EGFR TKIs with osimertinib in treatment of patients who develop C797S mutations. Another potential approach to treatment of C797X mutations may be to use novel allosteric EGFR inhibitors (EAI045 and JBJ-04-125-02), which are currently being investigated in preclinical studies $[129,130]$. Additionally, targeting gene fusions in combination with osimertinib in EGFR-mutated lung adenocarcinoma patients with either ALK-positive or RET-positive fusions was suggested to confer higher efficacy in this subset of patients, and warrants further validation in larger cohorts [131,132].

Given that enhanced MET signaling provides a significant source of resistance to osimertinib, targeting of this signaling pathway represents a promising approach. As mentioned previously, amivantamab is a bispecific antibody against EGFR and cMET that has shown activity and is currently being investigated in EGFR-mutated lung adenocarcinoma [124]. The TATTON study is a multi-center phase $1 \mathrm{~b}$ open label trial that investigated the safety and efficacy of a potent selective c-MET inhibitor (savolitinib) plus osimertinib in lung adenocarcinoma patients who had MET amplification upon progression to EGFR TKI [133]. Combination therapy demonstrated an acceptable safety profile and high ORR reaching $64 \%$ in patients who received savolitinib. A phase II trial (SAVANNAH) is underway to evaluate the safety and efficacy of a savolitinib and osimertinib combination in EGFR-mutated lung adenocarcinoma patients who progress on osimertinib with detected MET amplification (NCT03778229, ClinicalTrials.gov).

Another important phase II clinical trial (ORCHARD) currently underway follows a unique design to evaluate the efficacy, safety, and tolerability of several novel therapeutics and combination treatments based on resistant mechanisms detected at time of progression on osimertinib (NCT03944772, ClinicalTrials.gov). Patients will receive different treatments including: osimertinib and savolitinib (for patients with MET amplification detected at progression to osimertinib); osimertinib and gefitinib (patients with EGFR C797X mutations); osimertinib and the EGFR targeting antibody necitumumab (patients with EGFR amplification); while another arm of patients who do not have a targetable biomarker will receive treatments such as ICI, chemotherapy, and osimertinib plus necitumumab [134].

Recently, overexpression of a surface membrane protein kinase receptor, AXL, was found to confer resistance to EGFR TKIs and to be associated with worse survival in lung cancer patients [135-137]. Currently, the inhibition of AXL tyrosine kinase receptor is being investigated as monotherapy or in combination with an EGFR TKI in lung cancer (NCT03255083 and NCT02729298, ClinicalTrials.gov). Finally, other novel EGFR TKIs are currently being evaluated for their safety and efficacy. For example, lazertinib (a novel third generation EGFR TKI) has demonstrated acceptable safety and high ORR (54\%) in a recent phase I/II trial in patients with EGFR mutations (including T790M) who had progressed on early generation EGFR TKIs [138].

\section{EGFR TKIs as Adjuvant Treatment in Locally Advanced EGFR-Mutated Lung Adenocarcinoma}

The concept of introducing systemic cancer treatment in locally advanced lung cancer and other cancer types as adjuvant treatment has gained momentum in the last decade. Several clinical trials demonstrated improved outcomes (in terms of either PFS or diseasefree survival used as primary endpoints) after the treatment of patients with ICIs in lung cancer, or BRAF-MEK inhibitors in locally advanced BRAF-mutated melanoma $[139,140]$. To this end, the prevalence of EGFR mutations in stage II and stage III lung adenocarcinoma is high (approximately 12\%) [141]. The first phase III randomized trial to evaluate the safety and efficacy of EGFR TKIs as adjuvant therapy in EGFR-mutated lung adenocarcinoma was ADJUVANT/CTONG 1104 [142]. This trial evaluated gefitinib versus chemotherapy in resected EGFR-mutated lung adenocarcinoma, and demonstrated significantly prolonged disease-free survival in patients who received gefitinib. However, final OS analysis showed 
no significant benefit with geftinib versus chemotherapy combination ( 75.5 vs. 62.8 months, respectively) [143].

Using a similar approach, the phase III randomized ADAURA trial evaluated clinical outcomes in patients with EGFR-mutated lung adenocarcinoma (Stage II-IIIA) who received osimertinib for three years after surgical resection [144]. At 24 months, the disease-free survival was $90 \%$ in the osimertinib group versus $44 \%$ in the placebo group $(p<0.001)$, which has led to the 2020 FDA approval of osimertinib for the adjuvant treatment of resectable EGFR-mutated lung adenocarcinoma. Interestingly, the trial demonstrated a decrease in both locoregional recurrence and distant metastases in the osimertinib arm compared to the placebo arm ( $7 \%$ and $4 \%$, versus $18 \%$ and $28 \%$, respectively); final OS analysis is awaited [144]. Notably, there was $82 \%$ risk reduction for brain metastases recurrence or death in the osimertinib-treated group. Currently, a phase III trial (NeoADAURA) is ongoing for the evaluation of osimertinib plus chemotherapy as a neoadjuvant approach prior to surgery in patients with locally advanced EGFR-mutated lung adenocarcinoma (NCT04351555, ClinicalTrials.gov).

\section{Conclusions}

The emergence of a broad class of potent EGFR TKIs has revolutionized the management of EGFR-mutated lung adenocarcinoma. The progress of the landscape of EGFR TKI therapeutics in lung cancer from early generation to osimertinib and beyond reflects the depth of knowledge achieved in the last decade. The most common prevalent sensitizing mutations, including exon 19 deletions and L858R point mutations are susceptible to all generations of EGFR TKIs. Given the significant results of the FLAURA trial and the emergence of T790M mutations during treatment with early generation EGFR TKI, osimertinib is considered the standard of care as a frontline therapy in EGFR-mutated lung adenocarcinoma patients in the US and EU, and development of other new TKIs capable of inhibiting common resistance mutations is of high interest. Overall, acquired resistance remains a compelling challenge in the research and clinical field. To this end, recent trials and the availability of novel therapeutics and combination treatments have the potential to overcome resistance and improve outcomes in patients, particularly those with less common EGFR mutations. Finally, the recent implementation of EGFR TKIs in multimodality treatment of locally advanced EGFR-mutated lung adenocarcinoma represents a new precision medicine approach which promises to improve outcomes in these patients.

Author Contributions: Conceptualization, K.K., S.J. and Y.B.; methodology, K.K., S.J. and Y.B.; writing-original draft preparation, K.K.; writing-review and editing, K.K., E.G., A.D. and Y.B.; supervision, Y.B.; funding acquisition, E.G. and Y.B.; final review, K.K., E.G., A.D., M.E.A., J.D.P., H.B. and Y.B. All authors have read and agreed to the published version of the manuscript.

Funding: Y.B. is supported by NIH R01 CA218802 grant, Jimmy V Foundation T2018-013 Translational Award grant, by the Russian Government Program for Competitive Growth of Kazan Federal University. Y.B and J.P. were supported by the NCI Core Grant P30 CA060553 (to Robert H Lurie Comprehensive Cancer Center at Northwestern University). E.G. and A.D. were supported by NCI Core Grant P30 CA006927 (to Fox Chase Cancer Center), by NIH P50 DE030707, DOD CA201045/13193314, and with support from the William Wikoff Smith Charitable Trust (to EAG). M.E.A. was supported by NIH R37 CA222294, NIH P30CA060553, and the American Lung Association LCD565365.

Acknowledgments: Some figures created by licensed BioRender.

Conflicts of Interest: The authors declare no conflict of interest.

\section{References}

1. Siegel, R.L.; Miller, K.D.; Fuchs, H.E.; Jemal, A. Cancer Statistics, 2021. CA A Cancer J. Clin. 2021, 71, 7-33. [CrossRef] [PubMed]

2. Ward, W.H.; Cook, P.N.; Slater, A.M.; Davies, D.H.; Holdgate, G.A.; Green, L.R. Epidermal growth factor receptor tyrosine kinase. Investigation of catalytic mechanism, structure-based searching and discovery of a potent inhibitor. Biochem. Pharmacol. 1994, 48, 659-666. [CrossRef] 
3. Pollack, V.A.; Savage, D.M.; Baker, D.A.; Tsaparikos, K.E.; Sloan, D.E.; Moyer, J.D.; Barbacci, E.G.; Pustilnik, L.R.; Smolarek, T.A.; Davis, J.A.; et al. Inhibition of epidermal growth factor receptor-associated tyrosine phosphorylation in human carcinomas with CP-358,774: Dynamics of receptor inhibition in situ and antitumor effects in athymic mice. J. Pharmacol. Exp. Ther. 1999, 291, 739-748. [PubMed]

4. Fukuoka, M.; Yano, S.; Giaccone, G.; Tamura, T.; Nakagawa, K.; Douillard, J.Y.; Nishiwaki, Y.; Vansteenkiste, J.; Kudoh, S.; Rischin, D.; et al. Multi-institutional randomized phase II trial of gefitinib for previously treated patients with advanced non-small-cell lung cancer (The IDEAL 1 Trial) [corrected]. J. Clin. Oncol. 2003, 21, 2237-2246. [CrossRef]

5. $\quad$ Kris, M.G.; Natale, R.B.; Herbst, R.S.; Lynch, T.J., Jr.; Prager, D.; Belani, C.P.; Schiller, J.H.; Kelly, K.; Spiridonidis, H.; Sandler, A.; et al. Efficacy of gefitinib, an inhibitor of the epidermal growth factor receptor tyrosine kinase, in symptomatic patients with non-small cell lung cancer: A randomized trial. JAMA 2003, 290, 2149-2158. [CrossRef] [PubMed]

6. Kim, E.S.; Hirsh, V.; Mok, T.; Socinski, M.A.; Gervais, R.; Wu, Y.L.; Li, L.Y.; Watkins, C.L.; Sellers, M.V.; Lowe, E.S.; et al. Gefitinib versus docetaxel in previously treated non-small-cell lung cancer (INTEREST): A randomised phase III trial. Lancet 2008, 372, 1809-1818. [CrossRef]

7. Lynch, T.J.; Bell, D.W.; Sordella, R.; Gurubhagavatula, S.; Okimoto, R.A.; Brannigan, B.W.; Harris, P.L.; Haserlat, S.M.; Supko, J.G.; Haluska, F.G.; et al. Activating mutations in the epidermal growth factor receptor underlying responsiveness of non-small-cell lung cancer to gefitinib. N. Engl. J. Med. 2004, 350, 2129-2139. [CrossRef]

8. Paez, J.G.; Jänne, P.A.; Lee, J.C.; Tracy, S.; Greulich, H.; Gabriel, S.; Herman, P.; Kaye, F.J.; Lindeman, N.; Boggon, T.J.; et al. EGFR mutations in lung cancer: Correlation with clinical response to gefitinib therapy. Science 2004, 304, 1497-1500. [CrossRef]

9. Pao, W.; Miller, V.; Zakowski, M.; Doherty, J.; Politi, K.; Sarkaria, I.; Singh, B.; Heelan, R.; Rusch, V.; Fulton, L.; et al. EGF receptor gene mutations are common in lung cancers from "never smokers" and are associated with sensitivity of tumors to gefitinib and erlotinib. Proc. Natl. Acad. Sci. USA 2004, 101, 13306-13311. [CrossRef] [PubMed]

10. Shepherd, F.A.; Rodrigues Pereira, J.; Ciuleanu, T.; Tan, E.H.; Hirsh, V.; Thongprasert, S.; Campos, D.; Maoleekoonpiroj, S.; Smylie, M.; Martins, R.; et al. National Cancer Institute of Canada Clinical Trials Group. Erlotinib in previously treated non-small-cell lung cancer. N. Engl. J. Med. 2005, 353, 123-132. [CrossRef]

11. Zhou, C.; Wu, Y.L.; Chen, G.; Feng, J.; Liu, X.Q.; Wang, C.; Zhang, S.; Wang, J.; Zhou, S.; Ren, S.; et al. Erlotinib versus chemotherapy as first-line treatment for patients with advanced EGFR mutation-positive non-small-cell lung cancer (OPTIMAL, CTONG-0802): A multicentre, open-label, randomised, phase 3 study. Lancet Oncol. 2011, 12, 735-742. [CrossRef]

12. Zhou, C.; Wu, Y.L.; Chen, G.; Feng, J.; Liu, X.Q.; Wang, C.; Zhang, S.; Wang, J.; Zhou, S.; Ren, S.; et al. Final overall survival results from a randomised, phase III study of erlotinib versus chemotherapy as first-line treatment of EGFR mutation-positive advanced non-small-cell lung cancer (OPTIMAL, CTONG-0802). Ann. Oncol. 2015, 26, 1877-1883. [CrossRef]

13. Rosell, R.; Carcereny, E.; Gervais, R.; Vergnenegre, A.; Massuti, B.; Felip, E.; Palmero, R.; Garcia-Gomez, R.; Pallares, C.; Sanchez, J.M.; et al. Spanish Lung Cancer Group in collaboration with Groupe Français de Pneumo-Cancérologie and Associazione Italiana Oncologia Toracica. Erlotinib versus standard chemotherapy as first-line treatment for European patients with advanced EGFR mutation-positive non-small-cell lung cancer (EURTAC): A multicentre, open-label, randomised phase 3 trial. Lancet Oncol. 2012, 13, 239-246. [CrossRef] [PubMed]

14. Wu, Y.L.; Zhou, C.; Liam, C.K.; Wu, G.; Liu, X.; Zhong, Z.; Lu, S.; Cheng, Y.; Han, B.; Chen, L.; et al. First-line erlotinib versus gemcitabine/cisplatin in patients with advanced EGFR mutation-positive non-small-cell lung cancer: Analyses from the phase III, randomized, open-label, ENSURE study. Ann. Oncol. 2015, 26, 1883-1889. [CrossRef] [PubMed]

15. Maemondo, M.; Inoue, A.; Kobayashi, K.; Sugawara, S.; Oizumi, S.; Isobe, H.; Gemma, A.; Harada, M.; Yoshizawa, H.; Kinoshita, I.; et al. North-East Japan Study Group. Gefitinib or chemotherapy for non-small-cell lung cancer with mutated EGFR. N. Engl. J. Med. 2010, 362, 2380-2388. [CrossRef] [PubMed]

16. Mitsudomi, T.; Morita, S.; Yatabe, Y.; Negoro, S.; Okamoto, I.; Tsurutani, J.; Seto, T.; Satouchi, M.; Tada, H.; Hirashima, T.; et al. Gefitinib versus cisplatin plus docetaxel in patients with non-small-cell lung cancer harbouring mutations of the epidermal growth factor receptor (WJTOG3405): An open label, randomised phase 3 trial. Lancet Oncol. 2010, 11, 121-128. [CrossRef]

17. Yoshioka, H.; Shimokawa, M.; Seto, T.; Morita, S.; Yatabe, Y.; Okamoto, I.; Tsurutani, J.; Satouchi, M.; Hirashima, T.; Atagi, S.; et al. Final overall survival results of WJTOG3405, a randomized phase III trial comparing gefitinib versus cisplatin with docetaxel as the first-line treatment for patients with stage IIIB/IV or postoperative recurrent EGFR mutation-positive non-small-cell lung cancer. Ann. Oncol. 2019, 30, 1978-1984. [CrossRef] [PubMed]

18. Fukuoka, M.; Wu, Y.L.; Thongprasert, S.; Sunpaweravong, P.; Leong, S.S.; Sriuranpong, V.; Chao, T.Y.; Nakagawa, K.; Chu, D.T.; Saijo, N.; et al. Biomarker analyses and final overall survival results from a phase III, randomized, open-label, first-line study of gefitinib versus carboplatin/paclitaxel in clinically selected patients with advanced non-small-cell lung cancer in Asia (IPASS). J. Clin. Oncol. 2011, 29, 2866-2874. [CrossRef] [PubMed]

19. Mok, T.S.; Wu, Y.L.; Thongprasert, S.; Yang, C.H.; Chu, D.T.; Saijo, N.; Sunpaweravong, P.; Han, B.; Margono, B.; Ichinose, Y.; et al. Gefitinib or carboplatin-paclitaxel in pulmonary adenocarcinoma. N. Engl. J. Med. 2009, 361, 947-957. [CrossRef]

20. Sequist, L.V.; Yang, J.C.; Yamamoto, N.; O’Byrne, K.; Hirsh, V.; Mok, T.; Geater, S.L.; Orlov, S.; Tsai, C.M.; Boyer, M.; et al. Phase III study of afatinib or cisplatin plus pemetrexed in patients with metastatic lung adenocarcinoma with EGFR mutations. J. Clin. Oncol. 2013, 31, 3327-3334. [CrossRef] 
21. Wu, Y.L.; Zhou, C.; Hu, C.P.; Feng, J.; Lu, S.; Huang, Y.; Li, W.; Hou, M.; Shi, J.H.; Lee, K.Y.; et al. Afatinib versus cisplatin plus gemcitabine for first-line treatment of Asian patients with advanced non-small-cell lung cancer harbouring EGFR mutations (LUX-Lung 6): An open-label, randomised phase 3 trial. Lancet Oncol. 2014, 15, 213-222. [CrossRef]

22. Park, K.; Tan, E.H.; O’Byrne, K.; Zhang, L.; Boyer, M.; Mok, T.; Hirsh, V.; Yang, J.C.; Lee, K.H.; Lu, S.; et al. Afatinib versus gefitinib as first-line treatment of patients with EGFR mutation-positive non-small-cell lung cancer (LUX-Lung 7): A phase 2B, open-label, randomised controlled trial. Lancet Oncol. 2016, 17, 577-589. [CrossRef]

23. Wu, Y.L.; Cheng, Y.; Zhou, X.; Lee, K.H.; Nakagawa, K.; Niho, S.; Tsuji, F.; Linke, R.; Rosell, R.; Corral, J.; et al. Dacomitinib versus gefitinib as first-line treatment for patients with EGFR-mutation-positive non-small-cell lung cancer (ARCHER 1050): A randomised, open-label, phase 3 trial. Lancet Oncol. 2017, 18, 1454-1466. [CrossRef]

24. Mok, T.S.; Cheng, Y.; Zhou, X.; Lee, K.H.; Nakagawa, K.; Niho, S.; Lee, M.; Linke, R.; Rosell, R.; Corral, J.; et al. Improvement in Overall Survival in a Randomized Study That Compared Dacomitinib With Gefitinib in Patients with Advanced Non-Small-Cell Lung Cancer and EGFR-Activating Mutations. J. Clin. Oncol. 2018, 36, 2244-2250. [CrossRef] [PubMed]

25. Soria, J.C.; Ohe, Y.; Vansteenkiste, J.; Reungwetwattana, T.; Chewaskulyong, B.; Lee, K.H.; Dechaphunkul, A.; Imamura, F.; Nogami, N.; Kurata, T.; et al. FLAURA Investigators. Osimertinib in Untreated EGFR-Mutated Advanced Non-Small-Cell Lung Cancer. N. Engl. J. Med. 2018, 378, 113-125. [CrossRef] [PubMed]

26. Ramalingam, S.S.; Vansteenkiste, J.; Planchard, D.; Cho, B.C.; Gray, J.E.; Ohe, Y.; Zhou, C.; Reungwetwattana, T.; Cheng, Y.; Chewaskulyong, B.; et al. FLAURA Investigators. Overall Survival with Osimertinib in Untreated, EGFR-Mutated Advanced NSCLC. N. Engl. J. Med. 2020, 382, 41-50. [CrossRef] [PubMed]

27. Kawaguchi, T.; Matsumura, A.; Fukai, S.; Tamura, A.; Saito, R.; Zell, J.; Maruyama, Y.; Ziogas, A.; Kawahara, M.; Ou, S.-H.I. Japanese Ethnicity Compared with Caucasian Ethnicity and Never-Smoking Status Are Independent Favorable Prognostic Factors for Overall Survival in Non-small Cell Lung Cancer: A Collaborative Epidemiologic Study of the National Hospital Organization Study Group for Lung Cancer (NHSGLC) in Japan and a Southern California Regional Cancer Registry Databases. J. Thorac. Oncol. 2010, 5, 1001-1010. [CrossRef]

28. Shi, Y.; Li, J.; Zhang, S.; Wang, M.; Yang, S.; Li, N.; Wu, G.; Liu, W.; Liao, G.; Cai, K.; et al. Molecular Epidemiology of EGFR Mutations in Asian Patients with Advanced Non-Small-Cell Lung Cancer of Adenocarcinoma Histology-Mainland China Subset Analysis of the PIONEER study. PLoS ONE 2015, 10, e0143515. [CrossRef] [PubMed]

29. Zhang, Y.-L.; Yuan, J.-Q.; Wang, K.-F.; Fu, X.-H.; Han, X.-R.; Threapleton, D.; Yang, Z.-Y.; Mao, C.; Tang, J.-L. The prevalence of EGFR mutation in patients with non-small cell lung cancer: A systematic review and meta-analysis. Oncotarget 2016, 7, 78985-78993. [CrossRef]

30. Rosell, R.; Moran, T.; Queralt, C.; Porta, R.; Cardenal, F.; Camps, C.; Majem, M.; Lopez-Vivanco, G.; Isla, D.; Provencio, M.; et al. Screening for Epidermal Growth Factor Receptor Mutations in Lung Cancer. N. Engl. J. Med. 2009, 361, 958-967. [CrossRef]

31. D'Angelo, S.P.; Pietanza, M.C.; Johnson, M.L.; Riely, G.J.; Miller, V.A.; Sima, C.S.; Zakowski, M.F.; Rusch, V.W.; Ladanyi, M.; Kris, M.G. Incidence of EGFR Exon 19 Deletions and L858R in Tumor Specimens from Men and Cigarette Smokers with Lung Adenocarcinomas. J. Clin. Oncol. 2011, 29, 2066-2070. [CrossRef] [PubMed]

32. Han, B.; Tjulandin, S.; Hagiwara, K.; Normanno, N.; Wulandari, L.; Laktionov, K.; Hudoyo, A.; He, Y.; Zhang, Y.-P.; Wang, M.-Z.; et al. EGFR mutation prevalence in Asia-Pacific and Russian patients with advanced NSCLC of adenocarcinoma and non-adenocarcinoma histology: The IGNITE study. Lung Cancer 2017, 113, 37-44. [CrossRef] [PubMed]

33. Chan, S.W.; Maske, C.P.; Ruff, P. EGFR Mutations in Non-Small Cell Lung Cancer in South Africa. Ann. Oncol. 2015, 26, i1. [CrossRef]

34. Benbrahim, Z.; Antonia, T.; Mellas, N. EGFR mutation frequency in Middle East and African non-small cell lung cancer patients: A systematic review and meta-analysis. BMC Cancer 2018, 18, 891. [CrossRef]

35. Stone, E.; Allen, H.A.; Saghaie, T.; Abbott, A.; Daniel, R.; Mead, R.S.; Kohonen-Corish, M.; Plit, M.; Morgan, L. High proportion of rare and compound epidermal growth factor receptor mutations in an Australian population of non-squamous non-small-cell lung cancer. Intern. Med. J. 2014, 44, 1188-1192. [CrossRef]

36. Arrieta, O.; Cardona, A.F.; Martín, C.; Mas, L.; Corrales-Rodríguez, L.; Bramuglia, G.; Castillo-Fernandez, O.; Meyerson, M.; Amieva-Rivera, E.; Campos-Parra, A.D.; et al. Updated Frequency of EGFR and KRAS Mutations in NonSmall-Cell Lung Cancer in Latin America: The Latin-American Consortium for the Investigation of Lung Cancer (CLICaP). J. Thorac. Oncol. 2015, 10, 838-843. [CrossRef]

37. Dogan, S.; Shen, R.; Ang, D.C.; Johnson, M.L.; D’Angelo, S.P.; Paik, P.K.; Brzostowski, E.B.; Riely, G.J.; Kris, M.; Zakowski, M.F.; et al. Molecular Epidemiology of EGFR and KRAS Mutations in 3,026 Lung Adenocarcinomas: Higher Susceptibility of Women to Smoking-Related KRAS-Mutant Cancers. Clin. Cancer Res. 2012, 18, 6169-6177. [CrossRef]

38. Siegel, D.A.; Fedewa, S.A.; Henley, S.J.; Pollack, L.A.; Jemal, A. Proportion of Never Smokers Among Men and Women with Lung Cancer in 7 US States. JAMA Oncol. 2021, 7, 302. [CrossRef]

39. Campbell, J.D.; Cancer Genome Atlas Research Network; Alexandrov, A.; Kim, J.; Wala, J.; Berger, A.H.; Pedamallu, C.S.; Shukla, S.A.; Guo, G.; Brooks, A.N.; et al. Distinct patterns of somatic genome alterations in lung adenocarcinomas and squamous cell carcinomas. Nat. Genet. 2016, 48, 607-616. [CrossRef]

40. Midha, A.; Dearden, S.; McCormack, R. EGFR mutation incidence in non-small-cell lung cancer of adenocarcinoma histology: A systematic review and global map by ethnicity (mutMapII). Am. J. Cancer Res. 2015, 5, 2892-2911. 
41. The Cancer Genome Atlas Research Network. Author Correction: Comprehensive molecular profiling of lung adenocarcinoma. Nature 2018, 559, E12. [CrossRef]

42. Kobayashi, S.; Boggon, T.J.; Dayaram, T.; Jänne, P.A.; Kocher, O.; Meyerson, M.; Johnson, B.E.; Eck, M.J.; Tenen, D.G.; Halmos, B. EGFRMutation and Resistance of Non-Small-Cell Lung Cancer to Gefitinib. N. Engl. J. Med. 2005, 352, 786-792. [CrossRef] [PubMed]

43. Wang, Z.-F.; Ren, S.-X.; Li, W.; Gao, G.-H. Frequency of the acquired resistant mutation T790 M in non-small cell lung cancer patients with active exon 19Del and exon 21 L858R: A systematic review and meta-analysis. BMC Cancer 2018, 18, 148. [CrossRef] [PubMed]

44. Oxnard, G.R.; Arcila, M.E.; Sima, C.S.; Riely, G.J.; Chmielecki, J.; Kris, M.; Pao, W.; Ladanyi, M.; Miller, V.A. Acquired Resistance to EGFR Tyrosine Kinase Inhibitors in EGFR-Mutant Lung Cancer: Distinct Natural History of Patients with Tumors Harboring the T790M Mutation. Clin. Cancer Res. 2010, 17, 1616-1622. [CrossRef] [PubMed]

45. Yu, H.A.; Arcila, M.E.; Rekhtman, N.; Sima, C.S.; Zakowski, M.F.; Pao, W.; Kris, M.G.; Miller, V.A.; Ladanyi, M.; Riely, G.J. Analysis of Tumor Specimens at the Time of Acquired Resistance to EGFR-TKI Therapy in 155 Patients with EGFR-Mutant Lung Cancers. Clin. Cancer Res. 2013, 19, 2240-2247. [CrossRef] [PubMed]

46. Goss, G.; Tsai, C.-M.; Shepherd, F.A.; Bazhenova, L.; Lee, J.S.; Chang, G.-C.; Crino, L.; Satouchi, M.; Chu, Q.; Hida, T.; et al. Osimertinib for pretreated EGFR Thr790Met-positive advanced non-small-cell lung cancer (AURA2): A multicentre, open-label, single-arm, phase 2 study. Lancet Oncol. 2016, 17, 1643-1652. [CrossRef]

47. Sharma, S.V.; Bell, D.W.; Settleman, J.; Haber, D.A. Epidermal growth factor receptor mutations in lung cancer. Nat. Rev. Cancer 2007, 7, 169-181. [CrossRef]

48. Shan, Y.; Eastwood, M.P.; Zhang, X.; Kim, E.T.; Arkhipov, A.; Dror, R.O.; Jumper, J.; Kuriyan, J.; Shaw, D.E. Oncogenic Mutations Counteract Intrinsic Disorder in the EGFR Kinase and Promote Receptor Dimerization. Cell 2012, 149, 860-870. [CrossRef]

49. Kobayashi, S.; Canepa, H.M.; Bailey, A.S.; Nakayama, S.; Yamaguchi, N.; Goldstein, M.A.; Huberman, M.S.; Costa, D.B. Compound EGFR Mutations and Response to EGFR Tyrosine Kinase Inhibitors. J. Thorac. Oncol. 2013, 8, 118-122. [CrossRef]

50. Yun, C.-H.; Mengwasser, K.E.; Toms, A.V.; Woo, M.S.; Greulich, H.; Wong, K.K.; Meyerson, M.; Eck, M.J. The T790M mutation in EGFR kinase causes drug resistance by increasing the affinity for ATP. Proc. Natl. Acad. Sci. USA 2008, 105, 2070-2075. [CrossRef]

51. Cross, D.A.E.; Ashton, S.E.; Ghiorghiu, S.; Eberlein, C.; Nebhan, C.A.; Spitzler, P.J.; Orme, J.P.; Finlay, M.R.V.; Ward, R.A.; Mellor, M.J.; et al. AZD9291, an Irreversible EGFR TKI, Overcomes T790M-Mediated Resistance to EGFR Inhibitors in Lung Cancer. Cancer Discov. 2014, 4, 1046-1061. [CrossRef]

52. Corre, R.; Gervais, R.; Guisier, F.; Tassy, L.; Vinas, F.; Lamy, R.; Fraboulet, G.; Greillier, L.; Doubre, H.; Descourt, R.; et al Octogenarians with EGFR-mutated non-small cell lung cancer treated by tyrosine-kinase inhibitor: A multicentric real-world study assessing tolerance and efficacy (OCTOMUT study). Oncotarget 2018, 9, 8253-8262. [CrossRef] [PubMed]

53. Yoshioka, H.; Komuta, K.; Imamura, F.; Kudoh, S.; Seki, A.; Fukuoka, M. Efficacy and safety of erlotinib in elderly patients in the phase IV POLARSTAR surveillance study of Japanese patients with non-small-cell lung cancer. Lung Cancer 2014, 86, 201-206. [CrossRef] [PubMed]

54. De Marinis, F.; Wu, Y.-L.; De Castro, G.; Chang, G.-C.; Chen, Y.-M.; Cho, B.C.; Freitas, H.C.; Jiang, L.; Kim, S.-W.; Martin, C.; et al. ASTRIS: A global real-world study of osimertinib in $>3000$ patients with EGFR T790M positive non-small-cell lung cancer. Futur. Oncol. 2019, 15, 3003-3014. [CrossRef] [PubMed]

55. Auliac, J.B.; Pérol, M.; Planchard, D.; Monnet, I.; Wislez, M.; Doubre, H.; Guisier, F.; Pichon, E.; Greillier, L.; Mastroianni, B.; et al. Real-life efficacy of osimertinib in pretreated patients with advanced non-small cell lung cancer harboring EGFR T790M mutation. Lung Cancer 2019, 127, 96-102. [CrossRef] [PubMed]

56. Cao, Y.; Qiu, X.; Xiao, G.; Hu, H.; Lin, T. Effectiveness and safety of osimertinib in patients with metastatic EGFR T790M-positive NSCLC: An observational real-world study. PLoS ONE 2019, 14, e0221575. [CrossRef] [PubMed]

57. Kato, Y.; Hosomi, Y.; Watanabe, K.; Yomota, M.; Kawai, S.; Okuma, Y.; Kubota, K.; Seike, M.; Gemma, A.; Okamura, T. Impact of clinical features on the efficacy of osimertinib therapy in patients with T790M-positive non-small cell lung cancer and acquired resistance to epidermal growth factor receptor tyrosine kinase inhibitors. J. Thorac. Dis. 2019, 11, 2350-2360. [CrossRef]

58. Ettinger, D.S.; Wood, D.E.; Aggarwal, C.; Aisner, D.L.; Akerley, W.; Bauman, J.R.; Bharat, A.; Bruno, D.S.; Chang, J.Y.; Chirieac, L.R.; et al. NCCN Guidelines Insights: Non-Small Cell Lung Cancer, Version 1. J. Natl. Compr. Cancer Netw. 2019, 17, 1464-1472. [CrossRef]

59. Oizumi, S.; Kobayashi, K.; Inoue, A.; Maemondo, M.; Sugawara, S.; Yoshizawa, H.; Isobe, H.; Harada, M.; Kinoshita, I.; Okinaga, S.; et al. Quality of Life with Gefitinib in Patients with EGFR -Mutated Non-Small Cell Lung Cancer: Quality of Life Analysis of North East Japan Study Group 002 Trial. Oncologist 2012, 17, 863-870. [CrossRef]

60. Wei, Y.-F.; Huang, W.-T.; Liu, T.-C.; Shieh, J.-M.; Chian, C.-F.; Wu, M.-F.; Chang, C.-C.; Lin, C.-H.; Ko, J.-C.; Lin, C.-M.; et al. Factors associated with improvement in symptoms and quality of life for first-line EGFR-tyrosine kinase inhibitor treatment in patients with EGFR-mutated non-small-cell lung cancer-A multicenter prospective SMILE study. J. Cancer 2019, 10, 4151-4158. [CrossRef]

61. Aw, D.C.-W.; Tan, E.H.; Chin, T.M.; Lim, H.L.; Lee, H.Y.; Soo, R.A. Management of epidermal growth factor receptor tyrosine kinase inhibitor-related cutaneous and gastrointestinal toxicities. Asia-Pac. J. Clin. Oncol. 2017, 14, 23-31. [CrossRef] 
62. Liu, H.-B.; Wu, Y.; Lv, T.-F.; Yao, Y.-W.; Xiao, Y.-Y.; Yuan, D.-M.; Song, Y. Skin Rash could Predict the Response to EGFR Tyrosine Kinase Inhibitor and the Prognosis for Patients with Non-Small Cell Lung Cancer: A Systematic Review and Meta-Analysis. PLoS ONE 2013, 8, e55128. [CrossRef]

63. Califano, R.; Tariq, N.; Compton, S.N.; Fitzgerald, D.A.; Harwood, C.A.; Lal, R.; Lester, J.N.; McPhelim, J.; Mulatero, C.; Subramanian, S.; et al. Expert Consensus on the Management of Adverse Events from EGFR Tyrosine Kinase Inhibitors in the UK. Drugs 2015, 75, 1335-1348. [CrossRef]

64. Solassol, I.; Pinguet, F.; Quantin, X. FDA- and EMA-Approved Tyrosine Kinase Inhibitors in Advanced EGFR-Mutated Non-Small Cell Lung Cancer: Safety, Tolerability, Plasma Concentration Monitoring, and Management. Biomolecules 2019, 9, 668. [CrossRef]

65. Harrison, P.T.; Vyse, S.; Huang, P.H. Rare epidermal growth factor receptor (EGFR) mutations in non-small cell lung cancer. Semin. Cancer Biol. 2020, 61, 167-179. [CrossRef] [PubMed]

66. Kobayashi, Y.; Mitsudomi, T. Not all epidermal growth factor receptor mutations in lung cancer are created equal: Perspectives for individualized treatment strategy. Cancer Sci. 2016, 107, 1179-1186. [CrossRef]

67. Chiu, C.-H.; Yang, C.-T.; Shih, J.-Y.; Huang, M.-S.; Su, W.-C.; Lai, R.-S.; Wang, C.-C.; Hsiao, S.-H.; Lin, Y.-C.; Ho, C.-L.; et al. Epidermal Growth Factor Receptor Tyrosine Kinase Inhibitor Treatment Response in Advanced Lung Adenocarcinomas with G719X/L861Q/S768I Mutations. J. Thorac. Oncol. 2015, 10, 793-799. [CrossRef] [PubMed]

68. Yang, J.C.-H.; Sequist, L.V.; Geater, S.L.; Tsai, C.-M.; Mok, T.; Schuler, M.; Yamamoto, N.; Yu, C.-J.; Ou, S.H.; Zhou, C.; et al. Clinical activity of afatinib in patients with advanced non-small-cell lung cancer harbouring uncommon EGFR mutations: A combined post-hoc analysis of LUX-Lung 2, LUX-Lung 3, and LUX-Lung. Lancet Oncol. 2015, 16, 830-838. [CrossRef]

69. Ahn, M.-J.; Cho, J.H.; Sun, J.-M.; Lee, S.-H.; Ahn, J.S.; Park, K.; Park, K.U.; Kang, E.J.; Choi, Y.H.; Kim, K.H.; et al. An open-label, multicenter, phase II single arm trial of osimertinib in non-small cell lung cancer patients with uncommon EGFR mutation (KCSG-LU15-09). J. Clin. Oncol. 2018, 36, 9050. [CrossRef]

70. 70. Politi K, Lynch TJ. Two sides of the same coin: EGFR exon 19 deletions and insertions in lung cancer. Clin Cancer Res. 2012, 18, 1490-1492. [CrossRef]

71. He, M.; Capelletti, M.; Nafa, K.; Yun, C.-H.; Arcila, M.E.; Miller, V.A.; Ginsberg, M.S.; Zhao, B.; Kris, M.; Eck, M.J.; et al. EGFR Exon 19 Insertions: A New Family of Sensitizing EGFR Mutations in Lung Adenocarcinoma. Clin. Cancer Res. 2012, 18, $1790-1797$. [CrossRef] [PubMed]

72. Arcila, M.E.; Nafa, K.; Chaft, J.E.; Rekhtman, N.; Lau, C.; Reva, B.A.; Zakowski, M.F.; Kris, M.; Ladanyi, M. EGFR Exon 20 Insertion Mutations in Lung Adenocarcinomas: Prevalence, Molecular Heterogeneity, and Clinicopathologic Characteristics. Mol. Cancer Ther. 2013, 12, 220-229. [CrossRef] [PubMed]

73. Beau-Faller, M.; Prim, N.; Ruppert, A.-M.; Nanni-Metéllus, I.; Lacave, R.; Lacroix, L.; Escande, F.; Lizard, S.; Pretet, J.-L.; Rouquette, I.; et al. Rare EGFR exon 18 and exon 20 mutations in non-small-cell lung cancer on 10117 patients: A multicentre observational study by the French ERMETIC-IFCT network. Ann. Oncol. 2014, 25, 126-131. [CrossRef]

74. Naidoo, J.; Sima, C.S.; Bs, K.R.; Busby, N.; Nafa, K.; Ladanyi, M.; Riely, G.J.; Kris, M.; Arcila, M.E.; Yu, H.A. Epidermal growth factor receptor exon 20 insertions in advanced lung adenocarcinomas: Clinical outcomes and response to erlotinib. Cancer 2015, 121, 3212-3220. [CrossRef]

75. Jänne, P.A.; Boss, D.S.; Camidge, D.R.; Britten, C.D.; Engelman, J.A.; Garon, E.B.; Guo, F.; Wong, S.; Liang, J.; Letrent, S.; et al. Phase I Dose-Escalation Study of the Pan-HER Inhibitor, PF299804, in Patients with Advanced Malignant Solid Tumors. Clin. Cancer Res. 2011, 17, 1131-1139. [CrossRef]

76. Piotrowska, Z.; Wang, Y.; Sequist, L.V.; Ramalingam, S.S. ECOG-ACRIN 5162: A phase II study of osimertinib 160 mg in NSCLC with EGFR exon 20 insertions. J. Clin. Oncol. 2020, 38, 9513. [CrossRef]

77. Leventakos, K.; Kipp, B.R.; Rumilla, K.M.; Winters, J.L.; Yi, E.S.; Mansfield, A.S. S768I Mutation in EGFR in Patients with Lung Cancer. J. Thorac. Oncol. 2016, 11, 1798-1801. [CrossRef]

78. Banno, E.; Togashi, Y.; Nakamura, Y.; Chiba, M.; Kobayashi, Y.; Hayashi, H.; Terashima, M.; De Velasco, M.; Sakai, K.; Fujita, Y.; et al. Sensitivities to various epidermal growth factor receptor-tyrosine kinase inhibitors of uncommon epidermal growth factor receptor mutations L861Q and S768I: What is the optimal epidermal growth factor receptor-tyrosine kinase inhibitor? Cancer Sci. 2016, 107, 1134-1140. [CrossRef]

79. Rangachari, D.; Yamaguchi, N.; VanderLaan, P.A.; Folch, E.; Mahadevan, A.; Floyd, S.; Uhlmann, E.J.; Wong, E.T.; Dahlberg, S.; Huberman, M.S.; et al. Brain metastases in patients with EGFR -mutated or ALK -rearranged non-small-cell lung cancers. Lung Cancer 2015, 88, 108-111. [CrossRef] [PubMed]

80. Iuchi, T.; Shingyoji, M.; Itakura, M.; Yokoi, S.; Moriya, Y.; Tamura, H.; Yoshida, Y.; Ashinuma, H.; Kawasaki, K.; Hasegawa, Y.; et al. Frequency of brain metastases in non-small-cell lung cancer, and their association with epidermal growth factor receptor mutations. Int. J. Clin. Oncol. 2014, 20, 674-679. [CrossRef]

81. Offin, M.; Feldman, D.; Ni, A.; Myers, M.L.; Lai, W.V.; Pentsova, E.; Boire, A.; Daras, M.; Jordan, E.J.; Solit, D.B.; et al. Frequency and outcomes of brain metastases in patients with HER2 -mutant lung cancers. Cancer 2019, 125, 4380-4387. [CrossRef]

82. Li, L.; Luo, S.; Lin, H.; Yang, H.; Chen, H.; Liao, Z.; Lin, W.; Zheng, W.; Xie, X. Correlation between EGFR mutation status and the incidence of brain metastases in patients with non-small cell lung cancer. J. Thorac. Dis. 2017, 9, 2510-2520. [CrossRef] [PubMed] 
83. Reungwetwattana, T.; Nakagawa, K.; Cho, B.C.; Cobo, M.; Cho, E.K.; Bertolini, A.; Bohnet, S.; Zhou, C.; Lee, K.H.; Nogami, N.; et al. CNS Response to Osimertinib Versus Standard Epidermal Growth Factor Receptor Tyrosine Kinase Inhibitors in Patients With Untreated EGFR-Mutated Advanced Non-Small-Cell Lung Cancer. J. Clin. Oncol. 2018, 36, 3290-3297. [CrossRef] [PubMed]

84. Wu, Y.-L.; Ahn, M.-J.; Garassino, M.C.; Han, J.-Y.; Katakami, N.; Kim, H.R.; Hodge, R.; Kaur, P.; Brown, A.P.; Ghiorghiu, D.; et al. CNS Efficacy of Osimertinib in Patients With T790M-Positive Advanced Non-Small-Cell Lung Cancer: Data From a Randomized Phase III Trial (AURA3). J. Clin. Oncol. 2018, 36, 2702-2709. [CrossRef]

85. Magnuson, W.J.; Lester-Coll, N.; Wu, A.J.; Yang, T.J.; Lockney, N.; Gerber, N.K.; Beal, K.; Amini, A.; Patil, T.; Kavanagh, B.D.; et al. Management of Brain Metastases in Tyrosine Kinase Inhibitor-Naïve Epidermal Growth Factor Receptor-Mutant Non-Small-Cell Lung Cancer: A Retrospective Multi-Institutional Analysis. J. Clin. Oncol. 2017, 35, 1070-1077. [CrossRef] [PubMed]

86. Vyse, S.; Huang, P.H. Targeting EGFR exon 20 insertion mutations in non-small cell lung cancer. Signal Transduct. Target. Ther. 2019, 4, 51. [CrossRef]

87. Camidge, D.R.; Pao, W.; Sequist, L.V. Acquired resistance to TKIs in solid tumours: Learning from lung cancer. Nat. Rev. Clin. Oncol. 2014, 11, 473-481. [CrossRef]

88. Ramalingam, S.S.; Cheng, Y.; Zhou, C.; Ohe, Y.; Imamura, F.; Cho, B.C.; Lin, M.-C.; Majem, M.; Shah, R.; Rukazenkov, Y.; et al. Mechanisms of acquired resistance to first-line osimertinib: Preliminary data from the phase III FLAURA study. Ann. Oncol. 2018, 29, viii740. [CrossRef]

89. Leonetti, A.; Sharma, S.; Minari, R.; Perego, P.; Giovannetti, E.; Tiseo, M. Resistance mechanisms to osimertinib in EGFR-mutated non-small cell lung cancer. Br. J. Cancer 2019, 121, 725-737. [CrossRef]

90. Lichtenberger, B.M.; Tan, P.K.; Niederleithner, H.; Ferrara, N.; Petzelbauer, P.; Sibilia, M. Autocrine VEGF Signaling Synergizes with EGFR in Tumor Cells to Promote Epithelial Cancer Development. Cell 2010, 140, 268-279. [CrossRef]

91. Larsen, A.K.; Ouaret, D.; El Ouadrani, K.; Petitprez, A. Targeting EGFR and VEGF(R) pathway cross-talk in tumor survival and angiogenesis. Pharmacol. Ther. 2011, 131, 80-90. [CrossRef] [PubMed]

92. Minari, R.; Bordi, P.; Del Re, M.; Facchinetti, F.; Mazzoni, F.; Barbieri, F.; Camerini, A.; Comin, C.; Gnetti, L.; Azzoni, C.; et al. Primary resistance to osimertinib due to SCLC transformation: Issue of T790M determination on liquid re-biopsy. Lung Cancer 2018, 115, 21-27. [CrossRef] [PubMed]

93. Marcoux, N.; Gettinger, S.N.; O’Kane, G.; Arbour, K.C.; Neal, J.W.; Husain, H.; Evans, T.L.; Brahmer, J.R.; Muzikansky, A.; Bonomi, P.D.; et al. EGFR-Mutant Adenocarcinomas That Transform to Small-Cell Lung Cancer and Other Neuroendocrine Carcinomas: Clinical Outcomes. J. Clin. Oncol. 2019, 37, 278-285. [CrossRef]

94. Lee, J.G.; Wu, R. Erlotinib-Cisplatin Combination Inhibits Growth and Angiogenesis through c-MYC and HIF-1 $\alpha$ in EGFRMutated Lung Cancer In Vitro and In Vivo. Neoplasia 2015, 17, 190-200. [CrossRef] [PubMed]

95. La Monica, S.; Madeddu, D.; Tiseo, M.; Vivo, V.; Galetti, M.; Cretella, D.; Bonelli, M.; Fumarola, C.; Cavazzoni, A.; Falco, A.; et al. Combination of Gefitinib and Pemetrexed Prevents the Acquisition of TKI Resistance in NSCLC Cell Lines Carrying EGFRActivating Mutation. J. Thorac. Oncol. 2016, 11, 1051-1063. [CrossRef] [PubMed]

96. Cheng, Y.; Murakami, H.; Yang, P.-C.; He, J.; Nakagawa, K.; Kang, J.H.; Kim, J.-H.; Wang, X.; Enatsu, S.; Puri, T.; et al. Randomized Phase II Trial of Gefitinib With and Without Pemetrexed as First-Line Therapy in Patients With Advanced Nonsquamous Non-Small-Cell Lung Cancer With Activating Epidermal Growth Factor Receptor Mutations. J. Clin. Oncol. 2016, 34, 3258-3266. [CrossRef] [PubMed]

97. Hosomi, Y.; Morita, S.; Sugawara, S.; Kato, T.; Fukuhara, T.; Gemma, A.; Takahashi, K.; Fujita, Y.; Harada, T.; Minato, K.; et al. Gefitinib Alone Versus Gefitinib Plus Chemotherapy for Non-Small-Cell Lung Cancer With Mutated Epidermal Growth Factor Receptor: NEJ009 Study. J. Clin. Oncol. 2020, 38, 115-123. [CrossRef]

98. Noronha, V.; Patil, V.M.; Joshi, A.; Menon, N.; Chougule, A.; Mahajan, A.; Janu, A.; Purandare, N.; Kumar, R.; More, S.; et al. Gefitinib Versus Gefitinib Plus Pemetrexed and Carboplatin Chemotherapy in EGFR-Mutated Lung Cancer. J. Clin. Oncol. 2020, 38, 124-136. [CrossRef]

99. Naumov, G.N.; Nilsson, M.B.; Cascone, T.; Briggs, A.; Straume, O.; Akslen, L.A.; Lifshits, E.; Byers, L.A.; Xu, L.; Wu, H.-K.; et al. Combined Vascular Endothelial Growth Factor Receptor and Epidermal Growth Factor Receptor (EGFR) Blockade Inhibits Tumor Growth in Xenograft Models of EGFR Inhibitor Resistance. Clin. Cancer Res. 2009, 15, 3484-3494. [CrossRef]

100. Seto, T.; Kato, T.; Nishio, M.; Goto, K.; Atagi, S.; Hosomi, Y.; Yamamoto, N.; Hida, T.; Maemondo, M.; Nakagawa, K.; et al. Erlotinib alone or with bevacizumab as first-line therapy in patients with advanced non-squamous non-small-cell lung cancer harbouring EGFR mutations (JO25567): An open-label, randomised, multicentre, phase 2 study. Lancet Oncol. 2014, 15, 1236-1244. [CrossRef]

101. Stinchcombe, T.E.; Jänne, P.A.; Wang, X.; Bertino, E.M.; Weiss, J.; Bazhenova, L.; Gu, L.; Lau, C.; Paweletz, C.; Jaslowski, A.; et al. Effect of Erlotinib Plus Bevacizumab vs Erlotinib Alone on Progression-Free Survival in Patients with Advanced EGFR-Mutant Non-Small Cell Lung Cancer: A Phase 2 Randomized Clinical Trial. JAMA Oncol. 2019, 5, 1448-1455. [CrossRef] [PubMed]

102. Saito, H.; Fukuhara, T.; Furuya, N.; Watanabe, K.; Sugawara, S.; Iwasawa, S.; Tsunezuka, Y.; Yamaguchi, O.; Okada, M.; Yoshimori, K.; et al. Erlotinib plus bevacizumab versus erlotinib alone in patients with EGFR-positive advanced non-squamous non-small-cell lung cancer (NEJ026): Interim analysis of an open-label, randomised, multicentre, phase 3 trial. Lancet Oncol. 2019, 20, 625-635. [CrossRef] 
103. Maemondo, M.; Fukuhara, T.; Saito, H.; Furuya, N.; Watanabe, K.; Sugawara, S.; Iwasawa, S.; Tsunezuka, Y.; Yamaguchi, O.; Okada, M.; et al. NEJ026: Final overall survival analysis of bevacizumab plus erlotinib treatment for NSCLC patients harboring activating EGFR-mutations. J. Clin. Oncol. 2020, 38, 9506. [CrossRef]

104. Akamatsu, H.; Toi, Y.; Hayashi, H.; Fujimoto, D.; Tachihara, M.; Furuya, N.; Otani, S.; Shimizu, J.; Katakami, N.; Azuma, K.; et al. Efficacy of Osimertinib Plus Bevacizumab vs Osimertinib in Patients with EGFR T790M-Mutated Non-Small Cell Lung Cancer Previously Treated with Epidermal Growth Factor Receptor-Tyrosine Kinase Inhibitor: West Japan Oncology Group 8715L Phase 2 Randomized Clinical Trial. JAMA Oncol. 2021, 7, 386. [CrossRef] [PubMed]

105. Nakagawa, K.; Garon, E.B.; Seto, T.; Nishio, M.; Aix, S.P.; Paz-Ares, L.; Chiu, C.-H.; Park, K.; Novello, S.; Nadal, E.; et al. Ramucirumab plus erlotinib in patients with untreated, EGFR-mutated, advanced non-small-cell lung cancer (RELAY): A randomised, double-blind, placebo-controlled, phase 3 trial. Lancet Oncol. 2019, 20, 1655-1669. [CrossRef]

106. Reck, M.; Rodríguez-Abreu, D.; Robinson, A.G.; Hui, R.; Csőszi, T.; Fülöp, A.; Gottfried, M.; Peled, N.; Tafreshi, A.; Cuffe, S.; et al. Pembrolizumab versus Chemotherapy for PD-L1-Positive Non-Small-Cell Lung Cancer. N. Engl. J. Med. 2016, 375, 1823-1833. [CrossRef] [PubMed]

107. Gandhi, L.; Rodríguez-Abreu, D.; Gadgeel, S.; Esteban, E.; Felip, E.; De Angelis, F.; Domine, M.; Clingan, P.; Hochmair, M.J.; Powell, S.F.; et al. Pembrolizumab plus Chemotherapy in Metastatic Non-Small-Cell Lung Cancer. N. Engl. J. Med. 2018, 378, 2078-2092. [CrossRef] [PubMed]

108. Hellmann, M.D.; Paz-Ares, L.; Caro, R.B.; Zurawski, B.; Kim, S.-W.; Costa, E.C.; Park, K.; Alexandru, A.; Lupinacci, L.; De la Mora, J.E.; et al. Nivolumab plus ipilimumab in advanced non-small-cell lung cancer. N. Engl. J. Med. 2019, 381, 2020-2031. [CrossRef]

109. Gainor, J.F.; Shaw, A.T.; Sequist, L.V.; Fu, X.; Azzoli, C.G.; Piotrowska, Z.; Huynh, T.G.; Zhao, L.; Fulton, L.; Schultz, K.R.; et al. EGFR Mutations and ALK Rearrangements Are Associated with Low Response Rates to PD-1 Pathway Blockade in Non-Small Cell Lung Cancer: A Retrospective Analysis. Clin. Cancer Res. 2016, 22, 4585-4593. [CrossRef]

110. Lisberg, A.; Cummings, A.; Goldman, J.; Bornazyan, K.; Reese, N.; Wang, T.; Coluzzi, P.; Ledezma, B.; Mendenhall, M.; Hunt, J.; et al. A Phase II Study of Pembrolizumab in EGFR-Mutant, PD-L1+, Tyrosine Kinase Inhibitor Naïve Patients with Advanced NSCLC. J. Thorac. Oncol. 2018, 13, 1138-1145. [CrossRef]

111. Lee, C.K.; Man, J.; Lord, S.; Links, M.; Gebski, V.; Mok, T.; Yang, J.C.-H. Checkpoint Inhibitors in Metastatic EGFR- Mutated Non-Small Cell Lung Cancer-A Meta-Analysis. J. Thorac. Oncol. 2017, 12, 403-407. [CrossRef]

112. Adderley, H.; Blackhall, F.H.; Lindsay, C.R. Toxicity with small molecule and immunotherapy combinations in non-small cell lung cancer. Cancer Immunol. Immunother. 2021, 70, 589-595. [CrossRef]

113. Socinski, M.A.; Jotte, R.M.; Cappuzzo, F.; Orlandi, F.; Stroyakovskiy, D.; Nogami, N.; Rodríguez-Abreu, D.; Moro-Sibilot, D.; Thomas, C.A.; Barlesi, F. Atezolizumab for First-Line Treatment of Metastatic Nonsquamous NSCLC. N. Engl. J. Med. 2018, 378, 2288-2301. [CrossRef]

114. Reck, M.; Jotte, R.; Mok, T.; Lim, D.-T.; Cappuzzo, F.; Orlandi, F.; Stroyakovskiy, D.; Nogami, N.; Rodríguez-Abreu, D.; MoroSibilot, D.; et al. IMpower150: An exploratory analysis of efficacy outcomes in patients with EGFR mutations. Ann. Oncol. 2019, 30, ii48-ii49. [CrossRef]

115. Riess, J.W.; Gandara, D.R.; Frampton, G.M.; Madison, R.; Peled, N.; Bufill, J.A.; Dy, G.K.; Ou, S.-H.I.; Stephens, P.J.; McPherson, J.D.; et al. Diverse EGFR Exon 20 Insertions and Co-Occurring Molecular Alterations Identified by Comprehensive Genomic Profiling of NSCLC. J. Thorac. Oncol. 2018, 13, 1560-1568. [CrossRef] [PubMed]

116. Robichaux, J.P.; Elamin, Y.Y.; Tan, Z.; Carter, B.W.; Zhang, S.; Liu, S.; Li, S.; Chen, T.; Poteete, A.; Estrada-Bernal, A.; et al. Mechanisms and clinical activity of an EGFR and HER2 exon 20-selective kinase inhibitor in non-small cell lung cancer. Nat. Med. 2018, 24, 638-646. [CrossRef]

117. Wu, J.-Y.; Yu, C.-J.; Shih, J.-Y. Effectiveness of Treatments for Advanced Non-Small-Cell Lung Cancer with Exon 20 Insertion Epidermal Growth Factor Receptor Mutations. Clin. Lung Cancer 2019, 20, e620-e630. [CrossRef]

118. Van Veggel, B.; Santos, J.V.M.R.; Hashemi, S.; Paats, M.; Monkhorst, K.; Heideman, D.; Groves, M.; Radonic, T.; Smit, E.; Schuuring, E.; et al. Osimertinib treatment for patients with EGFR exon 20 mutation positive non-small cell lung cancer. Lung Cancer 2020, 141, 9-13. [CrossRef] [PubMed]

119. Fang, W.; Huang, Y.; Hong, S.; Zhang, Z.; Wang, M.; Gan, J.; Wang, W.; Guo, H.; Wang, K.; Zhang, L. EGFR exon 20 insertion mutations and response to osimertinib in non-small-cell lung cancer. BMC Cancer 2019, 19, 1-9. [CrossRef]

120. Neal, J.; Doebele, R.; Riely, G.; Spira, A.; Horn, L.; Piotrowska, Z.; Costa, D.; Zhang, S.; Bottino, D.; Zhu, J.; et al. P1.13-44 Safety, PK, and Preliminary Antitumor Activity of the Oral EGFR/HER2 Exon 20 Inhibitor TAK-788 in NSCLC. J. Thorac. Oncol. 2018, 13, S599. [CrossRef]

121. Riely, G.; Neal, J.; Camidge, D.; Spira, A.; Piotrowska, Z.; Horn, L.; Costa, D.; Tsao, A.; Patel, J.; Gadgeel, S.; et al. 1261MO Updated results from a phase I/II study of mobocertinib (TAK-788) in NSCLC with EGFR exon 20 insertions (exon20ins). Ann. Oncol. 2020, 31, S815-S816. [CrossRef]

122. Moores, S.L.; Chiu, M.; Bushey, B.S.; Chevalier, K.; Luistro, L.; Dorn, K.; Brezski, R.J.; Haytko, P.; Kelly, T.; Wu, S.-J.; et al. A Novel Bispecific Antibody Targeting EGFR and cMet Is Effective against EGFR Inhibitor-Resistant Lung Tumors. Cancer Res. 2016, 76, 3942-3953. [CrossRef] [PubMed]

123. Yun, J.; Lee, S.-H.; Kim, S.-Y.; Jeong, S.-Y.; Kim, J.-H.; Pyo, K.-H.; Park, C.-W.; Heo, S.G.; Yun, M.R.; Lim, S.; et al. Antitumor Activity of Amivantamab (JNJ-61186372), an EGFR-cMet Bispecific Antibody, in Diverse Models of EGFR Exon 20 Insertion-Driven NSCLC. Cancer Discov. 2020. [CrossRef] 
124. Park, K.; John, T.; Kim, S.-W.; Lee, J.S.; Shu, C.A.; Kim, D.-W.; Ramirez, S.V.; Spira, A.I.; Sabari, J.K.; Han, J.-Y.; et al. Amivantamab (JNJ-61186372), an anti-EGFR-MET bispecific antibody, in patients with EGFR exon 20 insertion (exon20ins)-mutated non-small cell lung cancer (NSCLC). J. Clin. Oncol. 2020, 38, 9512. [CrossRef]

125. Le, X.; Goldman, J.W.; Clarke, J.M.; Tchekmedyian, N.; Piotrowska, Z.; Chu, D.; Bhat, G.; Lebel, F.M.; Socinski, M.A. Poziotinib shows activity and durability of responses in subgroups of previously treated EGFR exon 20 NSCLC patients. J. Clin. Oncol. 2020, 38, 9514. [CrossRef]

126. Piotrowska, Z.; Nguyen, D.; Koczywas, M.; Tchekmedyian, N.; Clancy, M.; Witter, D.; Page, A.; Zawel, L.; Yu, H. 1345P Preliminary safety and activity of CLN-081 in NSCLC with EGFR exon 20 insertion mutations (Ins20). Ann. Oncol. 2020, 31, S862-S863. [CrossRef]

127. Arulananda, S.; Do, H.; Musafer, A.; Mitchell, P.; Dobrovic, A.; John, T. Combination Osimertinib and Gefitinib in C797S and T790M EGFR-Mutated Non-Small Cell Lung Cancer. J. Thorac. Oncol. 2017, 12, 1728-1732. [CrossRef]

128. Rangachari, D.; To, C.; Shpilsky, J.E.; VanderLaan, P.A.; Kobayashi, S.S.; Mushajiang, M.; Lau, C.J.; Paweletz, C.P.; Oxnard, G.R.; Jänne, P.A.; et al. EGFR-Mutated Lung Cancers Resistant to Osimertinib through EGFR C797S Respond to First-Generation Reversible EGFR Inhibitors but Eventually Acquire EGFR T790M/C797S in Preclinical Models and Clinical Samples. J. Thorac. Oncol. 2019, 14, 1995-2002. [CrossRef] [PubMed]

129. Jia, Y.; Yun, C.-H.; Park, E.; Ercan, D.; Manuia, M.; Juarez, J.; Xu, C.; Rhee, K.; Chen, T.; Zhang, H.; et al. Overcoming EGFR(T790M) and EGFR(C797S) resistance with mutant-selective allosteric inhibitors. Nature 2016, 534, 129-132. [CrossRef]

130. To, C.; Jang, J.; Chen, T.; Park, E.; Mushajiang, M.; De Clercq, D.J.; Xu, M.; Wang, S.; Cameron, M.D.; Heppner, D.E.; et al. Single and Dual Targeting of Mutant EGFR with an Allosteric Inhibitor. Cancer Discov. 2019, 9, 926-943. [CrossRef]

131. Mak, R.H.; Hermann, G.; Aerts, H.J.; Baldini, E.H.; Chen, A.B.; Kozono, D.; Rabin, M.S.; Swanson, S.J.; Chen, Y.-H.; Catalano, P.; et al. Outcomes by EGFR, KRAS, and ALK Genotype After Combined Modality Therapy for Locally Advanced Non-Small-Cell Lung Cancer. JCO Precis. Oncol. 2018, 2, 1-18. [CrossRef]

132. Piotrowska, Z.; Isozaki, H.; Lennerz, J.K.; Gainor, J.F.; Lennes, I.T.; Zhu, V.W.; Marcoux, N.; Banwait, M.K.; Digumarthy, S.R.; $\mathrm{Su}, \mathrm{W}$; ; et al. Landscape of Acquired Resistance to Osimertinib in EGFR-Mutant NSCLC and Clinical Validation of Combined EGFR and RET Inhibition with Osimertinib and BLU-667 for Acquired RET Fusion. Cancer Discov. 2018, 8, 1529-1539. [CrossRef] [PubMed]

133. Sequist, L.V.; Han, J.-Y.; Ahn, M.-J.; Cho, B.C.; Yu, H.; Kim, S.-W.; Yang, J.C.-H.; Lee, J.S.; Su, W.-C.; Kowalski, D.; et al. Osimertinib plus savolitinib in patients with EGFR mutation-positive, MET-amplified, non-small-cell lung cancer after progression on EGFR tyrosine kinase inhibitors: Interim results from a multicentre, open-label, phase 1b study. Lancet Oncol. 2020, 21, 373-386. [CrossRef]

134. Yu, H.; Goldberg, S.; Le, X.; Piotrowska, Z.; Smith, P.; Mensi, I.; Kirova, B.; Chmielecki, J.; Li-Sucholeicki, X.; Szekeres, P.; et al. P2.01-22 ORCHARD: A Phase II Platform Study in Patients with Advanced NSCLC Who Have Progressed on First-Line Osimertinib Therapy. J. Thorac. Oncol. 2019, 14, S647. [CrossRef]

135. Taniguchi, H.; Yamada, T.; Wang, R.; Tanimura, K.; Adachi, Y.; Nishiyama, A.; Tanimoto, A.; Takeuchi, S.; Araujo, L.H.; Boroni, M.; et al. AXL confers intrinsic resistance to osimertinib and advances the emergence of tolerant cells. Nat. Commun. 2019, 10, 1-14. [CrossRef] [PubMed]

136. Ishikawa, M.; Sonobe, M.; Nakayama, E.; Kobayashi, M.; Kikuchi, R.; Kitamura, J.; Imamura, N.; Date, H. Higher expression of receptor tyrosine kinase Axl, and differential expression of its ligand, Gas6, predict poor survival in lung adenocarcinoma patients. Ann. Surg. Oncol. 2013, 20 (Suppl. 3), S467-S476. [CrossRef]

137. Sato, K.; Suda, K.; Shimizu, S.; Sakai, K.; Mizuuchi, H.; Tomizawa, K.; Takemoto, T.; Nishio, K.; Mitsudomi, T. Clinical, Pathological, and Molecular Features of Lung Adenocarcinomas with AXL Expression. PLoS ONE 2016, 11, e0154186. [CrossRef] [PubMed]

138. Ahn, M.J.; Han, J.Y.; Lee, K.H.; Kim, S.W.; Kim, D.W.; Lee, Y.G.; Cho, E.K.; Kim, J.H.; Lee, G.W.; Lee, J.S.; et al. Lazertinib in patients with EGFR mutation-positive advanced non-small-cell lung cancer: Results from the dose escalation and dose expansion parts of a first-in-human, open-label, multicentre, phase 1-2 study. Lancet Oncol. 2019, 20, 1681-1690. [CrossRef]

139. Antonia, S.J.; Villegas, A.; Daniel, D.; Vicente, D.; Murakami, S.; Hui, R.; Yokoi, T.; Chiappori, A.; Lee, K.H.; de Wit, M.; et al. Pacific Investigators. Durvalumab after Chemoradiotherapy in Stage III Non-Small-Cell Lung Cancer. N. Engl. J. Med. 2017, 377, 1919-1929. [CrossRef] [PubMed]

140. Long, G.V.; Hauschild, A.; Santinami, M.; Atkinson, V.; Mandalà, M.; Chiarion-Sileni, V.; Larkin, J.; Nyakas, M.; Dutriaux, C.; Haydon, A.; et al. Adjuvant Dabrafenib plus Trametinib in Stage III BRAF-Mutated Melanoma. N. Engl. J. Med. 2017, 377, 1813-1823. [CrossRef]

141. Esteban, E.; Majem, M.; Martinez Aguillo, M.; Martinez Banaclocha, N.; Dómine, M.; Gómez Aldaravi, L.; Juan, O.; Cajal, R.; Gonzalez Arenas, M.C.; Provencio, M. Prevalence of EGFR mutations in newly diagnosed locally advanced or metastatic non-small cell lung cancer Spanish patients and its association with histological subtypes and clinical features: The Spanish REASON study. Cancer Epidemiol. 2015, 39, 291-297. [CrossRef]

142. Zhong, W.Z.; Wang, Q.; Mao, W.M.; Xu, S.T.; Wu, L.; Shen, Y.; Liu, Y.Y.; Chen, C.; Cheng, Y.; Xu, L.; et al. Adjuvant investigators. Gefitinib versus vinorelbine plus cisplatin as adjuvant treatment for stage II-IIIA (N1-N2) EGFR-mutant NSCLC (ADJUVANT/CTONG1104): A randomised, open-label, phase 3 study. Lancet Oncol. 2018, 19, 139-148. [CrossRef] 
143. Zhong, W.Z.; Wang, Q.; Mao, W.M.; Xu, S.T.; Wu, L.; Wei, Y.C.; Liu, Y.Y.; Chen, C.; Cheng, Y.; Yin, R.; et al. Gefitinib Versus Vinorelbine Plus Cisplatin as Adjuvant Treatment for Stage II-IIIA (N1-N2) EGFR-Mutant NSCLC: Final Overall Survival Analysis of CTONG1104 Phase III Trial. J. Clin. Oncol. 2020. [CrossRef]

144. Wu, Y.L.; Tsuboi, M.; He, J.; John, T.; Grohe, C.; Majem, M.; Goldman, J.W.; Laktionov, K.; Kim, S.W.; Kato, T.; et al. Adaura Investigators. Osimertinib in Resected EGFR-Mutated Non-Small-Cell Lung Cancer. N. Engl. J. Med. 2020, 383, $1711-1723$. [CrossRef] [PubMed] 